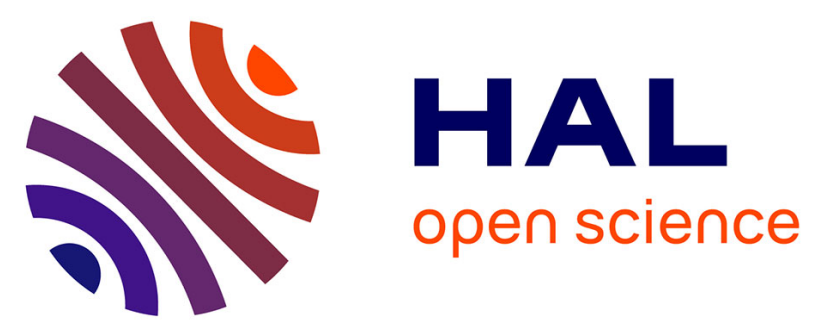

\title{
Recovery of the Island of Saint Martin after Hurricane Irma: An Interdisciplinary Perspective
}

Gwenaël Jouannic, Anaïs Ameline, Kelly Pasquon, Oscar Navarro, Chloé Tran

Duc Minh, A.H. Boudoukha, Marie-Aude Corbillé, Denis Crozier, Ghozlane

Fleury-Bahi, Julien Gargani, et al.

\section{To cite this version:}

Gwenaël Jouannic, Anaïs Ameline, Kelly Pasquon, Oscar Navarro, Chloé Tran Duc Minh, et al.. Recovery of the Island of Saint Martin after Hurricane Irma: An Interdisciplinary Perspective. Sustainability, 2020, 12 (20), pp.8585. 10.3390/su12208585 . hal-02970796

\section{HAL Id: hal-02970796 \\ https://hal.science/hal-02970796}

Submitted on 19 Oct 2020

HAL is a multi-disciplinary open access archive for the deposit and dissemination of scientific research documents, whether they are published or not. The documents may come from teaching and research institutions in France or abroad, or from public or private research centers.
L'archive ouverte pluridisciplinaire HAL, est destinée au dépôt et à la diffusion de documents scientifiques de niveau recherche, publiés ou non, émanant des établissements d'enseignement et de recherche français ou étrangers, des laboratoires publics ou privés. 


\title{
Recovery of the Island of Saint Martin after Hurricane Irma: An Interdisciplinary Perspective
}

\author{
Gwenaël Jouannic 1,2,*, Anaïs Ameline ${ }^{3}$, Kelly Pasquon ${ }^{1,4}$, Oscar Navarro ${ }^{3}$, \\ Chloé Tran Duc Minh ${ }^{1}$, Abdel Halim Boudoukha ${ }^{3}$, Marie-Aude Corbillé ${ }^{5}$, Denis Crozier ${ }^{1}$, \\ Ghozlane Fleury-Bahi ${ }^{3}$, Julien Gargani ${ }^{6,7}$ and Paul Guéro ${ }^{8}$ \\ 1 Cerema Ouest, 9 rue René Viviani, 44220 Nantes, France; kelly.pasquon@univ-nantes.fr (K.P.); \\ chloe.tran-duc-minh@cerema.fr (C.T.D.M.); denis.crozier@cerema.fr (D.C.) \\ 2 Cerema, EPR ESPRIM, 44220 Nantes, France \\ 3 Laboratoire de Psychologie des Pays de la Loire, University of Nantes, BP 81227-44312, Nantes Cedex 3, \\ 44000 Nantes, France; anais.ameline@univ-nantes.fr (A.A.); oscar.navarro@univ-nantes.fr (O.N.); \\ Abdel-Halim.Boudoukha@univ-nantes.fr (A.H.B.); Ghozlane.Fleury@univ-nantes.fr (G.F.-B.) \\ 4 Laboratoire de Planétologie et Géodynamique, CNRS UMR 6112, University of Nantes, 2 chemin de la \\ Houssinière, BP 92205, 44322 Nantes, France \\ 5 Cerema Centre Est, 46 Boulevard Saint Théobald, 38080 L'Isle d'Abeau, France; \\ Marie-Aude.Corbille@cerema.fr \\ 6 Geops, Université Paris-Saclay, CNRS, bat. 509, 91405 Orsay, France; \\ julien.gargani@universite-paris-saclay.fr \\ 7 Centre d'Alembert, Université Paris-Saclay, bat. 407, 91405 Orsay, France \\ 8 Cerema Méditerranée, Département Risques Eau Construction, 13100 Aix-en-Provence, France; \\ paul.guero@cerema.fr \\ * Correspondence: Gwenael.jouannic@cerema.fr
}

Received: 10 September 2020; Accepted: 13 October 2020; Published: 16 October 2020

\begin{abstract}
This study focuses on the ongoing recovery of the French part of the island of Saint Martin following Hurricane Irma in September 2017. The recovery of this semi-autonomous territory is a major challenge for local authorities and the French state. Based on the hypothesis that the consequences of natural disaster would be an opportunity for a territory to build back better, this study aims to understand the recovery trajectory that is underway on the island of Saint Martin 2 years after Hurricane Irma. Our analysis of Saint Martin's recovery from natural hazards is based on three factors: (1) the historical context and the evolution of building construction over the past 70 years; (2) the organization of local and national authorities; (3) the perception of the situation by the population. This original interdisciplinary approach of the post-disaster recovery phase provides a better understanding of the complexity of this period. The results of this study and the cross-analysis of these three methods highlight the causal links between the governance of the reconstruction, the psycho-sociological recovery of the disaster victims, and the history of the urbanization of an island exposed to natural hazards.
\end{abstract}

Keywords: Saint Martin; Hurricane Irma; resilience; urban planning; reconstruction governance; psycho-sociological recovery

\section{Introduction}

International institutions, through the ratification of the Hyogo and Sendai frameworks, invite member states to develop policies and mechanisms to ensure that disaster risk reduction is integrated into recovery and reconstruction efforts. However, countries that have introduced risk reduction policies into recovery planning often encounter difficulties in their implementation. In this respect, the current state of post-disaster recovery following Hurricanes Irma and Maria in the Lesser Antilles 
shows the difficulties of reconciling the two imperatives of "building back faster" and "building back better", in the context of social, political, and media pressure.

Our study focuses on the ongoing recovery of the island of Saint Martin following Hurricane Irma in September 2017. This hurricane, classified as category 5 on the Saffir-Simpson scale with average winds of $287 \mathrm{~km} / \mathrm{h}$ [1], highlighted the significant vulnerability of the West Indies to this type of natural hazard, and particularly the island of Saint Martin. The total cost of insured damage is estimated at 1.176 billion euros for the French part of Saint Martin [2]. When including uninsured property and the island of Saint Barthélemy, the total cost of damage could reach around three billion euros [2]. The day after Irma, the president of the local authority of Saint Martin, Daniel Gibbs, spoke of the destruction of $95 \%$ of the island and $60-70 \%$ of the houses [3]. In response to this exceptional situation, the French government has aimed to carry out a virtuous recovery effort in order to draw conclusions from the consequences of the disaster and seize the opportunity to revive the tourism economy, which had already weakened before Irma. A French government official report cited "a unique opportunity to rethink these territories differently" [4].

The aim of this study is to characterize the post-disaster recovery management of the French part of Saint Martin since Hurricane Irma impacted it in September 2017. The hypothesis of this work is that the reconstruction of an area affected by a natural hazard represents a temporal window of opportunity to sustainably build back the disaster area in a more resilient way with respect to future events. The main objective is the development of a method to better understand the management of post-disaster recovery on a territorial scale. Based on the case study of Saint Martin Island, we hope this work will help the local authorities of Saint Martin, and more broadly islands subject to hurricanes hazards, to improve the management of the post-hurricane recovery phase in order to cope with future events.

An interdisciplinary approach based on three methods was developed to better analyze Saint Martin's resilience to natural hazards: (1) a cartographical study of the evolution of building construction as well as the major changes in its environment since 1947, based on aerial photos; (2) analysis of the evolution of the organization of Saint Martin's institutions (French state, local authorities) before and after Irma; (3) a psycho-sociological analysis of Saint Martin's inhabitants to understand how the population perceives reconstruction after Irma. A cross-analysis of these methods was performed with the aim of better understanding the historical impact of past hurricanes on urban planning, the ways in which institutions are reorganized following a major disaster, and the perceptions of such an event by disaster victims. Two missions on Saint Martin ( 2 weeks in April 2019, 3 weeks in December 2019) allowed the field data collection. Each mission was composed of scientists from several disciplines (geography, urban planning, psychology, sociology, administrative law) in order to promote exchanges between disciplines.

The cross-analysis of these three methods allowed us to propose an original interpretation of Saint Martin's society in the face of hurricanes, with a particular focus on post-Irma recovery. In the short-term, this approach aims to contribute to the recovery of the territory by improving organization and communication between local decision-makers, infrastructure managers, and the inhabitants of sectors exposed to natural hazards. Upstream of future disasters here or elsewhere, these exchanges will also feed into the development of tools and methods to anticipate the organization of actors in charge of reconstruction, the involvement of populations in the reconstruction process, , and the physical reconstruction of damaged infrastructure.

\section{Study Area}

Since 1648, a frontier has divided the island of Saint Martin into two countries (Figure 1) - in the south is the Dutch part (St. Maarten) and in the north is the French part (Saint Martin). The French part covers $53 \mathrm{~km}^{2}$ with 35,700 inhabitants as of 2016, while the Dutch part has about 37,000 inhabitants across $37 \mathrm{~km}^{2}$ [5]. The French part is characterized by very strong recent demographic growth, growing from 8072 inhabitants in 1982 to 28,518 inhabitants in 1990 [5,6]. 


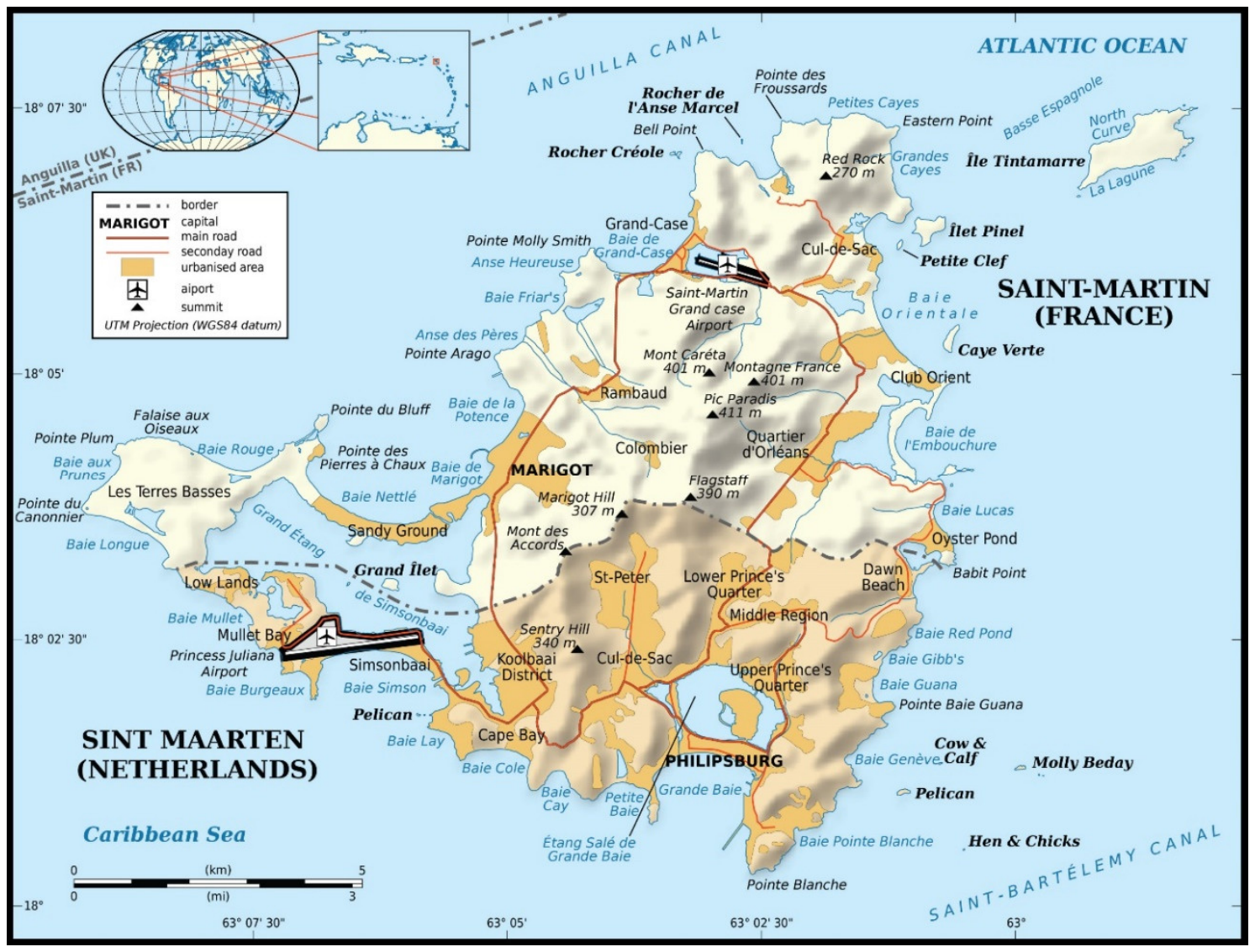

Figure 1. Map of the Caribbean island of Saint Martin, which is divided into French and Dutch halves (adapted from Eric Gaba).

In 2007, Saint Martin changed its status from a municipality attached to Guadeloupe to a relatively autonomous French overseas region (article 74 of the 1958 French Constitution). This change implied a new power distribution between the French state and the Saint Martin local authorities, with an increase of the powers devoted to Saint Martin, in particular with regard to urban planning, construction, and housing [7]. However, the French state remains able to lay down rules in several areas, including in the organization of justice, defense, public security, and the environment (including natural hazards).

In 1990, half of the population ( $51 \%)$ of the French part of Saint Martin was foreign [6,8], which decreased to $32 \%$ in 1999. In total, $35 \%$ of migrants were born in Haiti, $15 \%$ in Dominica, $15 \%$ in Northern Europe or North America, and 13\% in the Dominican Republic [9]. The rest of the population correspond to a French metropolitan and European population and a minority population native to Saint Martin [10]. Currently, 120 nationalities are represented in Saint Martin [11]. It is notable that French is only the fourth most spoken language, behind West Indian English, Creole, and Spanish. This creates a divide with the State services that use French as a priority.

In the next parts of the article, we refer to the French part of the island of Saint Martin as "Saint Martin" and the Dutch part as "Sint Maarten".

\section{Materials and Methods}

\subsection{Historical Data (1947-2017)}

The cartography of the evolution of building construction on Saint Martin, as well as the evolution of the environment, is based on aerial photos from France's IGN (https://remonterletemps.ign.fr/). In total, 776 photos of the island of Saint Martin from 12 photo campaigns ranging from 1947 to 2010 were used in this study (Figure 2). The time span between the photographic campaigns is irregular, with gaps ranging from two months to 15 years. This historical 
database provides a map of the evolution of the construction and reconstruction of buildings on the island of Saint Martin between 1954 and 2017 (before Irma) for each aerial photo campaign. A total of about 11,730 buildings were surveyed in at least seven aerial campaigns. In total, more than 100,000 observations were made.

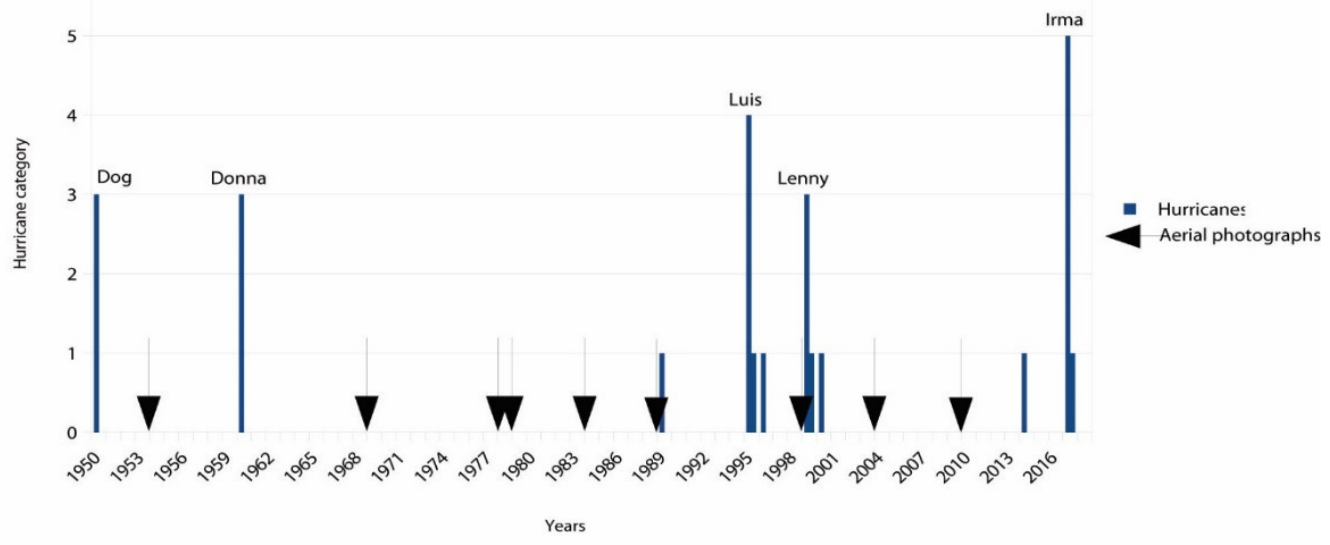

Figure 2. Chronology of aerial shots and past hurricanes impacting Saint Martin from 1950 to 2018.

In December 2019, a mission on Saint Martin island was conducted to achieve, among others, a cartographical assessment of the state of the reconstruction of buildings in some neighborhoods.

\subsection{Institutional Data}

Several sources of information were mobilized to understand the organization and role of institutions on Saint Martin, including interviews with stakeholders, newspaper reviews, and analysis of official reports. Firstly, about 20 semi-directive interviews with representatives of local and national French authorities in Saint Martin and Saint Barthélemy were conducted during a mission in April 2019 (Table 1). Secondly, we recovered 80 documents from local and national authorities who participated in or supported the recovery of the island. These documents deal widely with the subject of recovery in terms of its regulatory, political, administrative, and technical issues. A press review beginning in September 2017 completed this database, which contained about 250 articles from local and national newspapers.

Table 1. List of organizations interviewed.

\begin{tabular}{|c|c|c|}
\hline Organization & Department & Location \\
\hline \multirow{2}{*}{$\begin{array}{l}\text { Inter-ministerial delegation } \\
\text { for reconstruction }\end{array}$} & Inter-ministerial delegate for reconstruction & St. Martin \\
\hline & Territorial delegate for reconstruction & St. Martin \\
\hline Prefecture of Guadeloupe & Prefect & Guadeloupe \\
\hline \multirow{2}{*}{$\begin{array}{l}\text { Delegate Prefecture for St. } \\
\text { Martin and St. Barthélemy }\end{array}$} & Delegate Prefect & St. Martin \\
\hline & Prefect's head staff & St. Martin \\
\hline \multirow{4}{*}{$\begin{array}{l}\text { Department of the } \\
\text { Environment, Urban } \\
\text { Planning, and Housing } \\
\text { (DEAL) }\end{array}$} & $\begin{array}{l}\text { Department of Transport, Risks, Natural } \\
\text { Resources, Security, and Defense }\end{array}$ & Guadeloupe \\
\hline & $\begin{array}{l}\text { Department of Urban Planning, Construction, } \\
\text { Management, and Communication }\end{array}$ & Guadeloupe \\
\hline & Crisis management service & Guadeloupe \\
\hline & Natural hazard division & Guadeloupe \\
\hline \multirow{2}{*}{ St. Martin's DEAL units } & Natural Risks and Pollution Department & St. Martin \\
\hline & Urban Planning Department & St. Martin \\
\hline
\end{tabular}




\begin{tabular}{llc}
\hline & Geographic Information System division & St. Martin \\
\hline Commercial port & Manager & St. Martin \\
\hline \multirow{2}{*}{$\begin{array}{l}\text { Local authorities of St. } \\
\text { Martin }\end{array}$} & Sustainable Development Department & St. Martin \\
\cline { 2 - 3 } & Major risks division & St. Martin \\
\cline { 2 - 3 } $\begin{array}{l}\text { Local authorities of St. } \\
\text { Barthélemy }\end{array}$ & GIS division & St. Martin \\
\hline $\begin{array}{l}\text { Chamber of Commerce and } \\
\text { Industry }\end{array}$ & President's head staff & $\begin{array}{c}\text { St. } \\
\text { Presidency }\end{array}$ \\
\cline { 2 - 3 } Surveyor's office & Manager & St. Martin \\
\hline Architectural office & $/$ & $\begin{array}{c}\text { St. } \\
\text { Beparthélemy }\end{array}$ \\
\hline $\begin{array}{l}\text { Department of Enterprises } \\
\text { and Employment (DIECCTE) }\end{array}$ & Masiness Development Mission & St. Martin \\
\hline Coastline Institute & $/$ & Guadeloupe \\
\hline
\end{tabular}

\subsection{Psycho-Sociological Data}

\subsubsection{Sample and Procedure for the "Inhabitants" Category}

In total, 37 people were interviewed within the framework of this research study. All these people live on the island of Saint Martin and all experienced Hurricane Irma and the months following the disaster. Their origins vary (Saint Martin, the Caribbean in the broader sense, people from mainland France having resided on the island for a shorter or longer period, and so on), as do their professions (e.g., laborers, psychologists, social workers, market vendors, restorers, and administrative officials). The sample, therefore, enabled the collection of very varied accounts regarding the post-disaster recovery process (it was not possible to interview any children or adolescents).

Regarding the procedure, the inhabitants, volunteer association managers, and neighborhood representatives were contacted before the mission so that contact was made with the individuals volunteering to conduct the interviews. We contacted associations fighting against different forms of inequalities, associations engaged in the reconstruction, and environmental protection associations, for example. Thus, we wanted to contact different social groups in order to obtain the most representative sample. It was, thus, possible to set up a certain number of appointments beforehand. Nevertheless, the majority of interviews were agreed upon on site by asking the inhabitants directly.

\subsubsection{Material and Data Processing}

An interview guide was drawn up with a view to questioning the inhabitants about the major factors of the recovery (rebuilding of their residence and their life after Hurricane Irma), together with the long-term physical and psycho-sociological consequences of the hurricane. This enabled us to conduct semi-structured interviews, lasting from a few minutes to three hours. These interviews were recorded and transcribed, then analyzed using IRAMUTEQ software (Interface de R pour les Analyses Multidimensionnelles de Textes et de Questionnaires) [12-14]. This software statistically analyzes and classifies the internal organization of a speech. Concretely and succinctly, the analysis of co-occurring lexemes in simple statements of a text (ALCESTE, Analyse Lexicale par Contexte d'un Ensemble de Segments de Texte) method enables one to summarize the internal organization of a discourse. This technique consists of modeling the distribution of words in speech, as well as identifying the language patterns most used by different inhabitants. 


\section{Results}

\subsection{Urban Planning History (1947-2017)}

The number of buildings on Saint Martin has increased continuously since 1954 (Figure 3). Before 1954, only the neighborhoods of Grand-Case, Marigot, Saint-James, Agrément, Rambaud, Colombier, Cul-de-sac, and Orléans existed. There were numerous natural areas and the island was sparsely inhabited (Figure 4).

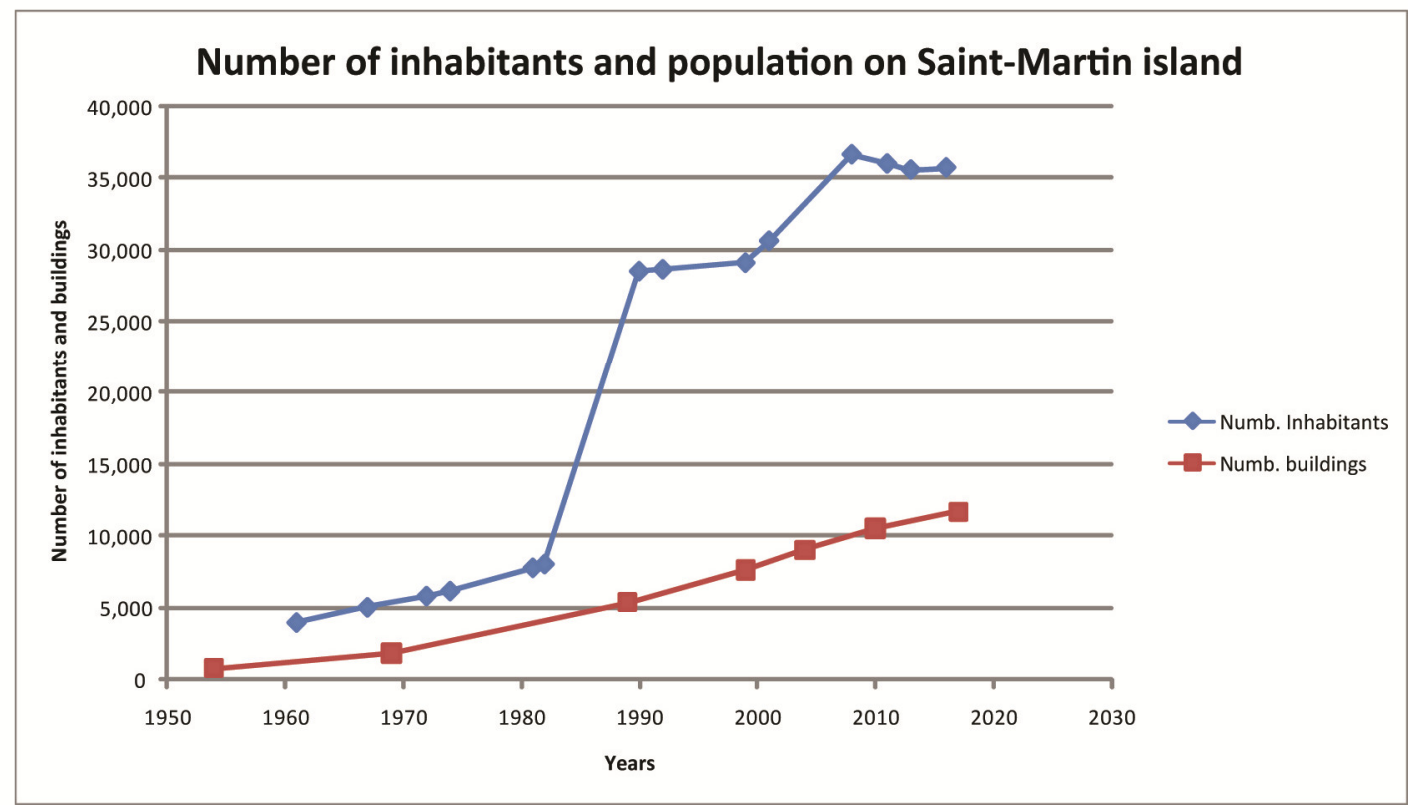

Figure 3. Graphs showing the increase in the total number of buildings from 1954 to 2017 (red curve) and the population growth (blue curve) from 1960 to 2016 (sources: Institut National de la Statistique et des Etudes Economiques, INSEE). 


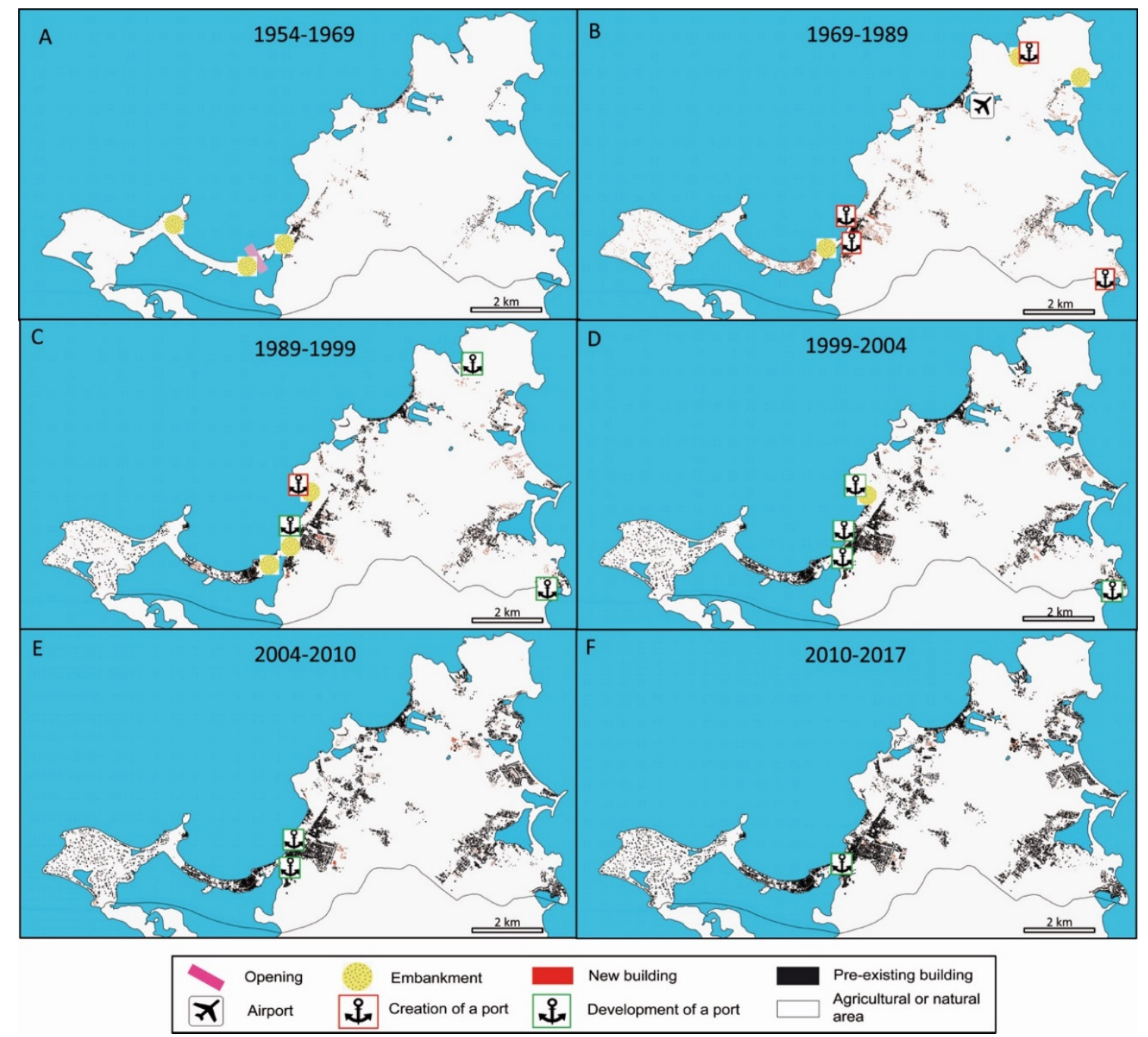

Figure 4. Global map of the urbanization of the French part of Saint Martin for the periods: (A) 19541969, (B) 1969-1989, (C) 1989-1999 (before Hurricane Lenny), (D) 1999 (before Hurricane Lenny)2004, (E) 2004-2010, and (F) 2010-2017 (before Hurricane Irma). Red rectangles show new buildings, black rectangles show existing buildings. The background map is an outline of the island in 2017 (before Hurricane Irma).

From 1954 to 1969, an average of 69 buildings a year were constructed (Figure 3, Table 2). The island's environment began to be modified - embankments appeared at Marigot, Sandy Ground, and at the transition between Nettle Bay and the Pointe du Bluff. The channel at Sandy Ground was dug, and the French part of Simpson Bay was then connected to the sea. Three existing neighborhoods developed-Marigot, Grand-Case, and Quartier d'Orléans. Relatively isolated buildings appeared at Terres Basses and the Pointe du Bluff, together with Sandy Ground. Buildings numbered 1840 in 1969 (Figure 4A). 
Table 2. Evolution of the number of buildings on Saint Martin between 1954 and 2017.

\begin{tabular}{cccc}
\hline Year & $\begin{array}{c}\text { Total Number of } \\
\text { Buildings }\end{array}$ & $\begin{array}{c}\text { Number of Buildings by } \\
\text { Period }\end{array}$ & $\begin{array}{c}\text { Average Number of Buildings } \\
\text { Built Yearly }\end{array}$ \\
\hline 1954 & 808 & 808 & 808 \\
1969 & 1836 & 1028 & 1028 \\
1989 & 5401 & 3565 & 3565 \\
1999 & 7665 & 2264 & 2264 \\
2004 & 9089 & 1424 & 1424 \\
2010 & 10,571 & 1482 & 1482 \\
2017 & 11,726 & 1155 & 1155 \\
\hline
\end{tabular}

Between 1969 and 1989, an average of 178 buildings were constructed yearly (Figure 3, Table 2). Large numbers of new buildings were erected at Terres Basses and Sandy Ground (an additional 330 and 526 buildings, respectively). The neighborhoods of Cul-de-Sac, Quartier d'Orléans, and around Marigot (Marigot, Saint-James, Agrément, Hameau du Pont/Spring) also grew significantly (136, 583, and 1086 new buildings, respectively). Urbanization began at Oyster Pond (110 new buildings), Anse Marcel (27 new buildings), and Nettle Bay (82 new buildings). Four marinas were created: two in Marigot, one in Anse Marcel and one in Oyster Pond. Grand-Case Airport was also built (Figure 4B). Sandy Ground, Anse Marcel, and Cul-de-Sac are observed to have filled significantly.

Between 1989 and 1999, an average of 226 buildings was constructed yearly (Figure 3, Table 2). More embankments appeared, mainly around Marigot and in Galisbay. Marinas were being developed and a commercial port was being created in Galisbay (Figure 4C). All neighborhoods on the island densified, but no new ones were created.

Between 1999 and 2004, an average of 285 buildings were built yearly (Figure 3, Table 2). The neighborhoods of Oyster Pond, Orient Bay, and Quartier d'Orléans developed, and Terres Basses densified (66, 230, 239, and 133 new buildings, respectively). Some neighborhoods, such as the one in Nettle Bay, seemed to develop no further. The industrial port developed (Figure 4D).

Between 2004 and 2010, 247 buildings were constructed on average yearly (Figure 3, Table 2). Urbanization increased throughout the island. The industrial zone of Hope Estate near the airport was developed (Figure 4E).

Finally, between 2010 and 2017 (before Irma), an average of 165 buildings yearly were constructed (Figure 3, Table 2). The densifying process continued throughout the island, reaching approximately 11,730 buildings in 2017 (Figure 4F).

Hurricane Irma in September 2017 caused extensive damage, with 5874 cases of negligible damage (46.5\% of buildings), 2940 cases of moderate damage (23.3\% of buildings), 1323 cases of severe damage (10.5\% of buildings), and 2486 cases of destroyed damage (19.7\% of buildings) (Copernicus EMS Risk and Recovery data). In comparison to the total number of buildings damaged in 2017 (12,623 buildings), in July 2018 78.3\% buildings were still damaged, 7.2\% buildings were removed, $6.8 \%$ buildings were under reconstruction, $5.4 \%$ buildings were rebuilt, and $2.2 \%$ new buildings were built (Copernicus EMS Risk and Recovery data). In July 2019 in comparison with the total buildings damaged in 2017, 66.2\% buildings were still damages, $7.4 \%$ buildings were removed, $7.0 \%$ buildings were under reconstruction, $16.8 \%$ buildings were rebuilt, and $2.5 \%$ new buildings were built (Copernicus EMS Risk and Recovery data).

The Oyster Pond neighborhood shows an example for observation of groups of damaged buildings. In 1999, three groups of buildings are present and in apparently good condition despite Hurricane Luis (in 1995) (Figure 5A). The three groups of buildings were damaged by Hurricane Lenny in 1999-the aerial photography from 2004 shows two groups still damaged by Hurricane Lenny, while one observed is destroyed (Figure 5B). One group was rebuilt between 2004 and 2010. Other one was always observed to be damaged and the last one was removed (Figure 5C). In 2017 (before Hurricane Irma), the building group destroyed in the previous image was re-built (Figure 5D). After Hurricane Irma, the three groups of building were damaged (Figure 5D) and in December 2019 they had not been rebuilt (Figure 5E). 

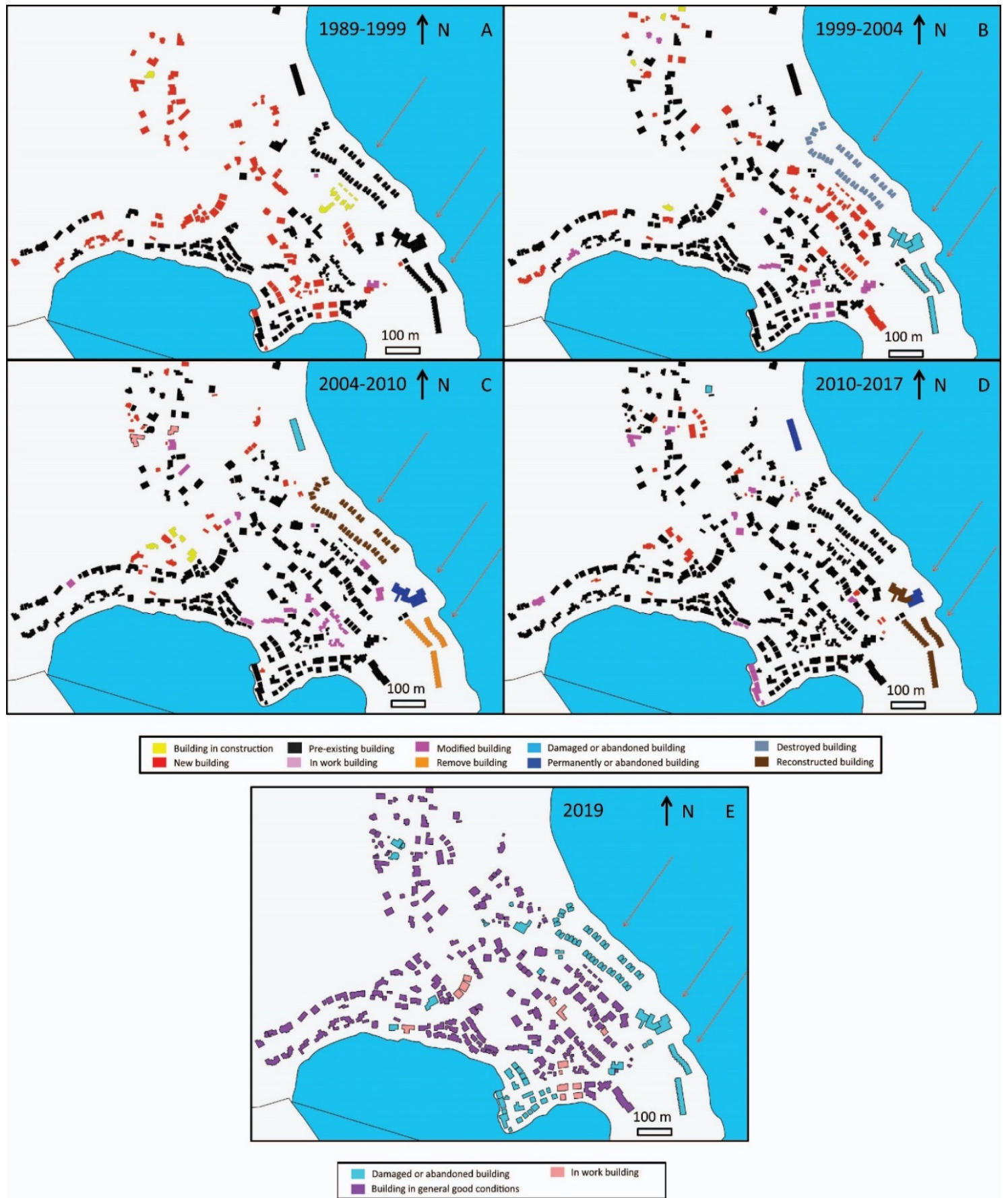

Figure 5. Example of damage buildings for the Oyster Pond neighborhood from 1999 to 2019 (aerial photography and fields observations): (A) 1989-1999 (after Hurricane Luis and before Hurricane Lenny); (B) 1999-2004; (C) 2004-2010 (after Hurricane Omar); (D) 2010-2017 (before Hurricane Irma); (E) 2019 (observation directly on the island). Arrows show groups of buildings studied in this picture.

Hurricane Luis (in 1995) damaged several buildings, such as the hotel "La Belle Créole" on the Pointe du Bluff near the neighborhoods of Terres Basses and the hotel located on Happy bay. 


\subsection{Institutional Recovery}

\subsubsection{Emergency Support to Local Institutions}

The extent of the damage has created a sense of absolute and exclusive urgency for further action. The will of the French Government to support the recovery of Saint Martin was immediately concretized with the setting up of a new committee in charge of the post-disaster phase.

During the French President's visit on 14 September 2017, 8 days after Irma, a newly appointed Inter-Ministerial Delegate for the Reconstruction of the Islands of Saint Martin and Saint Barthélemy accompanied the presidential delegation. Regarding post-Irma recovery, this interministerial delegate (Prefect Gustin), appointment alongside the Deputy Prefect of Saint Martin, reinforced the French government's mission (Figure 6). A "dedicated manager who has specific dedicated time and legitimacy to coordinate the different ministries" was clearly identified (taken from account by Prefect Gustin). Likewise, the deputy Prefect of Saint Martin could focus full-time on urgent crisis management. Recovery was, thus, a political objective that was clearly stated in speeches and actions the day after the disaster. A team of 6 people was formed by Prefect Gustin to support him in achieving his missions. This team was composed of an assistant, a territorial delegate for reconstruction, and 4 agents in charge of (1) financial engineering, (2) technical networks, (3) legal expertise and victim assistance, and (4) communication. Two months later, Prefect Gustin presented a report with the aim of creating a window of opportunity despite the technical, social, and political constraints (account of territorial delegate for reconstruction).

In the organization designed by the French state, the interministerial delegation was to be the linchpin of the recovery process. It launched initiatives and ensured dialogue with local authorities. Initially created for three months, it remained active for 15 months. It is of note that the interministerial delegation had neither an investment budget nor an operating budget. Prefect Gustin's first task required his presence mainly in Paris in order to mobilize the various ministries and create a network of referents among their services and cabinets. Such difficulties in mobilizing ministerial departments, for which post-disaster management is not a day-to-day priority, were been highlighted by the delegate for reconstruction of the Saguenay region in Canada [15]. In the case of Saint Martin, the set-up resulted in a significant number of meetings (30 meetings in two months), interministerial commissions, direct mobilization of ministers, and a hundred or so press interviews to defend the actions of the state (taken from interviews with Prefect Gustin). 
Evolution of government services

following Irma

simplified organization

\section{Before Irma}

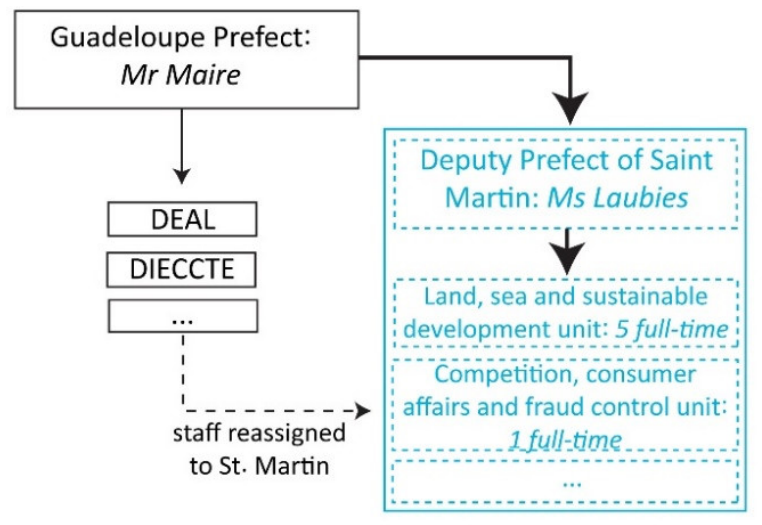

\section{Post-crisis}

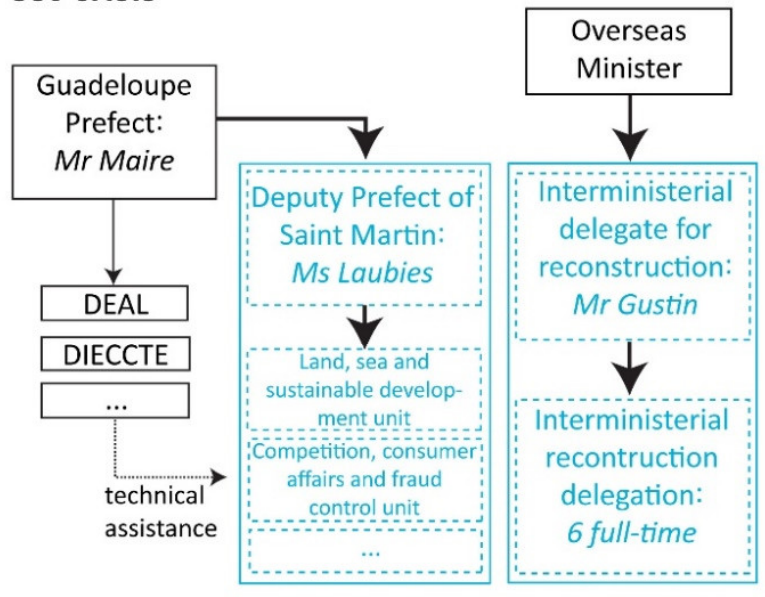

\section{After Irma}

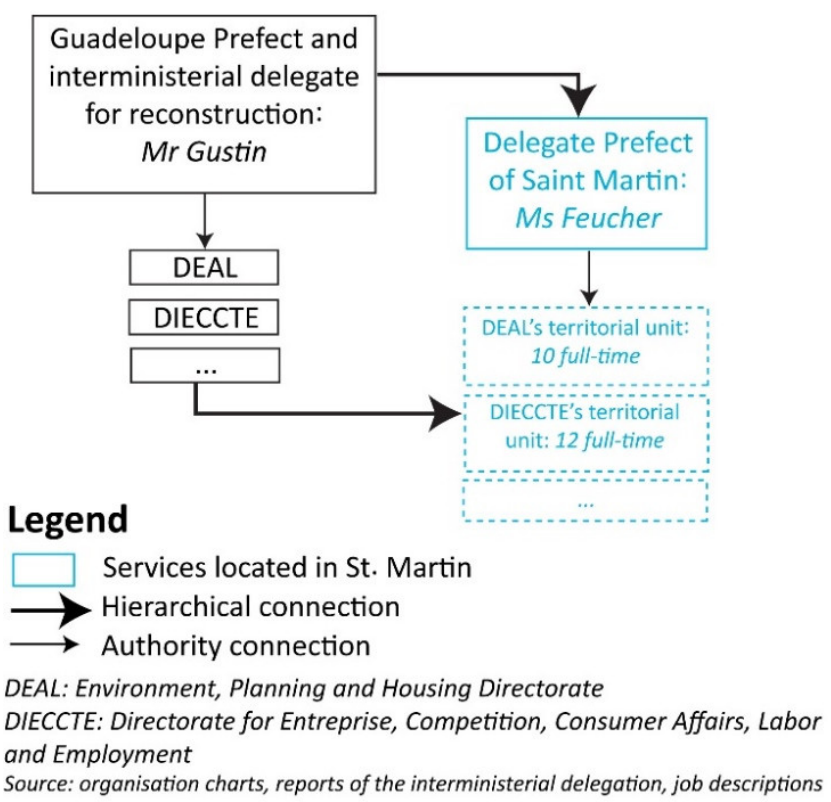

Figure 6. Diagram of the organization of French State Departments in Guadeloupe, Saint Martin, and Saint Barthélemy before Irma, during the post-crisis management, and two years after Irma. 
The willingness to act as a task force to move as quickly as possible was positive in several regards, including speed in decision-making (procedures for providing aid to businesses, procedures for obtaining planning permission after Irma, strengthening of the French State Department in Saint Martin, etc.). Prefect Gustin highlighted the lessons learnt from this specific organization in a report published a year after Irma: "The delegation acted as a real bridge between Saint Martin's local authorities and the Parisian officials, and was able to make a quick assessment of the Northern Islands after Hurricane Irma and make recommendations for exemplary and sustainable recovery. The interministerial work in Paris enabled a rapid, flexible response to the challenges by adapting procedures and 'inventing' ad hoc mechanisms" [2].

Finally, the interministerial delegation team spent most of the time to help local institutions manage the crisis due to the urgency of this exceptional situation, and prepared them for the establishment of a strengthened and sustainable organization of administrations. Regarding the population, the disaster-stricken inhabitants received emergency financial aid from the French government. The interministerial delegation launched a prepaid card ranging from 300 to 900 euros per family, distributed on social criteria from November 2017 to January 2018 to 4000 modest households in Saint Martin [2]. This aid was a first in France for a major disaster, which had a total estimated cost of 2 million euros.

Nevertheless, the interministerial delegation's main mission was first to learn from the consequences of Hurricane Irma on Saint Martin and to lay the foundations for a territorial recovery project. Faced with this ambitious objective and a short time of action, we observed at this stage of this work that the interministerial delegation did not have any human resources dedicated to consultation with the local population about the recovery project and the future of their territory.

In addition to the appointment of Prefect Gustin, a temporary and extensive system of organization was implemented to manage the crisis and anticipate recovery. A rotation of civil servants from Guadeloupe's Department of the French Ministry for the Environment (DEAL) and government officials was organized. These people were temporarily reassigned from their services to Saint Martin for two months, in order to support the recovery (taken from an account by the DEAL's official).

\subsubsection{Towards a Sustainable and Reinforced Reorganization}

Following the emergency of the crisis management, the major issue for local Saint Martin institutions was to create a new sustainable and reinforced organization, both for the French state and for the local authorities of Saint Martin.

A new sustainable organization of the French state on Saint Martin was established in June 2018, when Sylvie Feucher was appointed Delegate Prefect for Saint Martin and Saint Barthélemy, replacing the previous deputy prefect. Several recruitments were made to create a number of local units in order to support the public action of the prefecture (Figure 6). These new state departments are located in Marigot (Saint Martin) and temporary workspaces have been built to accommodate them. All these decisions are in accordance with the protocol signed between the French government and the local authorities of Saint Martin on 17 November 2017, two months after the hurricane, on the initiative of Prefect Gustin: "In Saint Martin, the state will ensure the permanent representation of several state departments currently located in Guadeloupe."

The Department of the Environment (including natural hazards), Urban Planning, and Housing (DEAL) currently has an official total of eight staff members on Saint Martin, including four managers. Two to four contract staff are likely to be added in order to reinforce this new department until the end of the recovery period. During the first few months after its creation, the people recruited in this new unit had to work closely with the interministerial delegation to enable continuity in the actions already undertaken.

Moreover, none of the new managers had ever worked in the West Indies, and the contract staff, who were recruited particularly for the issue of risks, had little experience with administrative procedures. Support from departments in the DEAL's headquarters in Guadeloupe was, therefore, necessary. For example, the risk prevention officer located in Guadeloupe considers that for a year 
and a half his Guadeloupian unit spent 30\% of its time on post-Irma management on Saint Martin. This temporary work investment in Saint Martin postponed missions initially planned for the island of Guadeloupe. The risk prevention department of DEAL in Guadeloupe also had to deal with the impacts of Hurricane Maria, which directly followed Irma and hit Guadeloupe 13 days after Hurricane Irma. The missions to follow on Saint Martin's issues, which were not previously planned, therefore appeared in an already difficult context. Saint Martin's DEAL unit was created as a measure to relieve the DEAL headquarters in Guadeloupe, and consequently the support from Guadeloupe quickly became more distant. In April 2019, an executive officer of DEAL in Guadeloupe stated: “The French state has provided resources specifically dedicated to Saint Martin-the local DEAL unit in Saint Martin must quickly become autonomous".

The present delegate prefect considers that the size of Saint Martin's DEAL unit is well-suited for day-to-day management, but is insufficient for the specific period of recovery, which is far from over (taken from an interview with the Delegate Prefect for Saint Martin and Saint Barthélemy). In particular, the delegated prefecture and Saint Martin's DEAL unit must rapidly carry out a complete revision of the Natural Hazards Prevention Plan (NHPP), which has to take into account the impacts of Hurricane Irma on urban planning.

For its part, Saint Martin's local authorities are undersized for an autonomous French overseas region, with complementary powers due to this specific statute, in particular with regard to urban planning, construction, and housing. These technical services structurally lack executives, managers, and organization to ensure the rapid processing of files related to the reconstruction (taken from testimonies of technicians from the state and local authorities of Saint Martin). Five experts paid by the Agence Française du Développement were made available to the Saint Martin local authorities to help with governance and advice on technical subjects such as financial engineering. Despite this one-time support, the Saint Martin local authorities continue to face significant challenges in managing the island's recovery.

Regarding the financing of the recovery, the method of financing was cumbersome and required significant human resources and strong skills in the writing of public contracts, which the Saint Martin local authorities does not have. The state's system of financing recovery does not facilitate the mobilization of funds, and the St. Martin local authorities is not sufficiently organized to apply for these funds within the imposed deadlines (taken from a testimony of an executive from local authorities of Saint Martin). The administrative burden of financing the recovery, which is putting the Saint Martin local authorities in difficulty, is a major factor in slowing down the island's recovery.

All of these factors contribute to fueling prejudice and mistrust between the local authorities of Saint Martin, the representatives of the French state in Guadeloupe and Metropolitan France, and the socio-economic actors.

Finally, we note once again that over this medium-term period of management of the reconstruction, neither the French state services located in Saint Martin nor the local authorities were able to find the human resources, financial means, or the time necessary to consult with the local population on the recovery project the island.

\subsection{Psycho-Sociological Recovery}

The psycho-sociological aim of this qualitative study was to understand how the inhabitants of Saint Martin perceived the psychological and physical recovery of their island and their lives after Hurricane Irma. To achieve this, content analysis was performed based on the 37 interviews conducted during our mission in situ. Data analysis using Iramuteq software used $84 \%$ of the elementary context units (ECUs) to form five classes (Figure 7): class 1, "immediate consequences of Hurricane Irma" (25\%); class 2, "material damage subsequent to Hurricane Irma" (21\%); class 3, "identities and future of the island of Saint Martin" (19\%); class 4, "medical and psychological aid and actors from the voluntary sector" (19\%); class 5, "economic problems linked to post-disaster recovery" $(16 \%)$. The statements of the inhabitants were initially structured around the immediate management of the crisis (peri-disaster, classes 2 and 3). Then, the issue of reconstruction in the medium- and long-term was approached (classes 1, 4, and 5). 


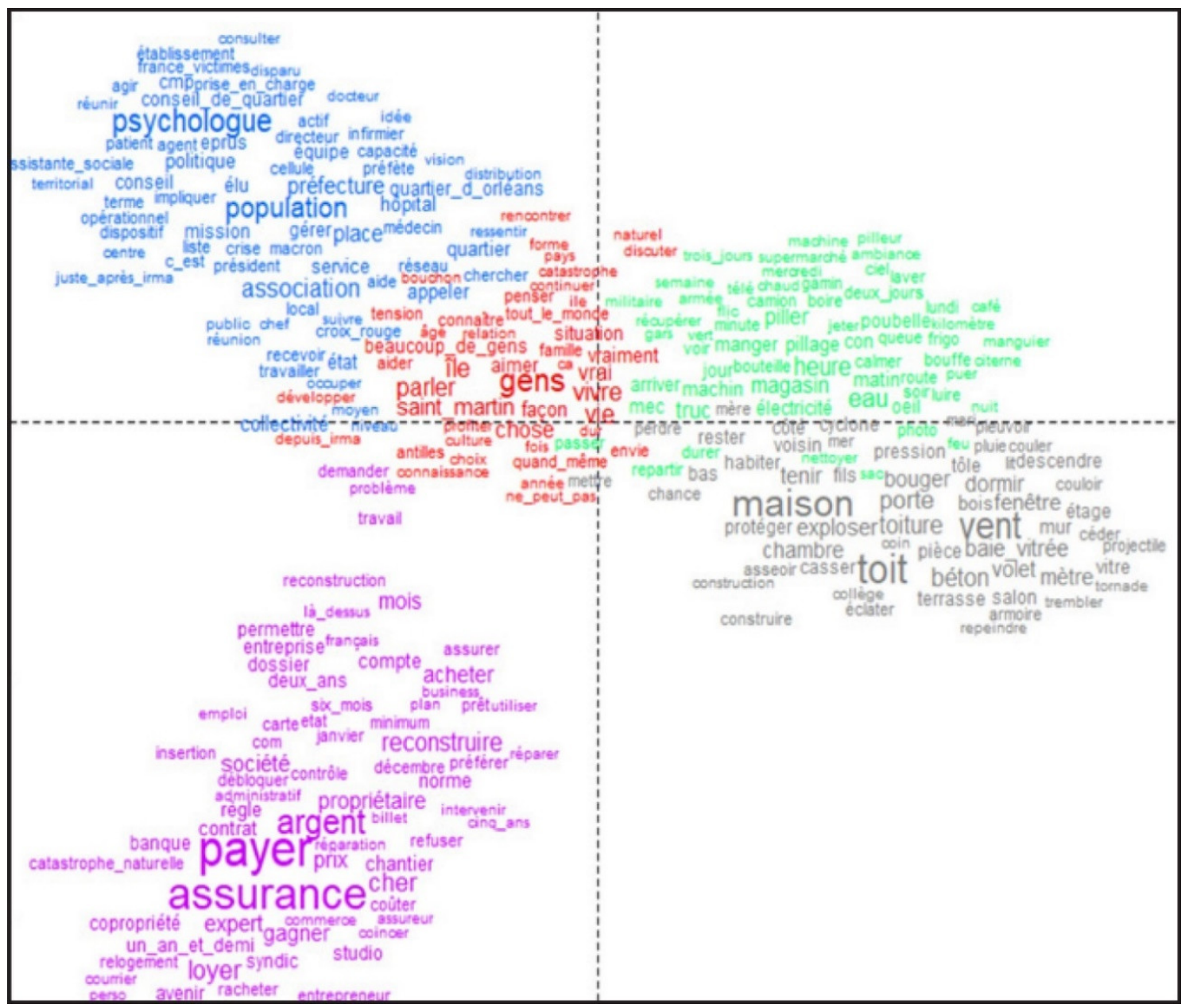

Figure 7. Factorial map based on the factor analysis of the correspondences representing the active forms. In green, class 1: immediate consequences of Hurricane Irma (25\%); in grey, class 2: material damage subsequent to Hurricane Irma (21\%); in red, class 3: identities and future of the island of Saint Martin (19\%); in blue, class 4: medical and psychological aid and actors from the voluntary sector (19\%); in purple, class 5: economic problems linked to post-disaster recovery (16\%). The interviews were conducted in French. We chose to keep French in this figure because our method of discourse analysis was based on this language (see Appendix A for English translation).

\subsubsection{Immediate Consequences of Hurricane Irma (Class 1)}

This first section, representing approximately $25 \%$ of the utterances, is named "immediate consequences of Hurricane Irma". These consequences fall into two main categories-the more material consequences and the psychosocial consequences with which they are interwoven. The material consequences are essentially approached through the significant presence of words such as "water" (X2 = 161; $p<0.001)$, "eat" (X2 = 81; $p<0.001)$, "trash can" $(X 2=66 ; p<0.001)$, "electricity" $(X 2=65 ; p<0.001)$, or "getting out" $(X 2=42 ; p<0.001)$ and "road" $(X 2=42 ; p<0.001)$. These words convey the absence of a certain number of resources following the hurricane. They also convey how life was organized in the initial days after the disaster in order to manage the emergency.

As for the psychosocial consequences, these are essentially approached via the significant presence of words such as "loot" $(X 2=109 ; p<0.001)$ or "looting" $(X 2=79 ; p<0.001)$. These accounts would appear to show that part of the population tolerates these thefts when the stolen goods are primary foodstuffs. However, this section of the population rejects looting when the stolen goods are products that are not necessary in a state of emergency. This is conveyed by elements of language such as "they went looting useful things in supermarkets, all kinds of pasta", and "they looted iPhones and television sets even though there was no electricity". Moreover, certain inhabitants 
experienced the looting as a double blow, affecting them worse than the hurricane itself: "But frankly, if there'd only been the wind, things would have been alright-the worst was the looting"; "they really went too far, we'd never seen anything like it". Finally, these scenes of looting seem to have generated anger: "We knew they'd looted everywhere, but foie gras and champagne-that's going too far, I'd be ashamed to loot that", together with a feeling of insecurity expressed by some of the inhabitants: "The looting started. So then we lit fires in the car park... But everything was looted. The residence opposite my place was emptied in the space of three nights. We had torches. And I had candles in jars to show there was life. The gate had come off. That's what scared me most."

\subsubsection{Material Damage following the Hurricane (Class 2)}

This part accounts for approximately $21 \%$ of the statements and is closely linked to those mentioned above. This category is termed "material damage following the hurricane". The damage is mainly described through the highly significant presence of words such as "roof" $(\mathrm{X} 2=335 ; p<$ 0.001), "house" $(\mathrm{X} 2=309 ; p<0.001)$, "wind" $(\mathrm{X} 2=273 ; p<0.001)$, "door" $(\mathrm{X} 2=159 ; p<0.001)$, or "explode" ( $\mathrm{X} 2=124 ; p<0.001)$. These words testify to the unprecedented violence of Hurricane Irma on the island of Saint Martin. Particular attention deserves to be paid to the word "concrete" $(\mathrm{X} 2=$ $141 ; p<0.001)$. Indeed, two forms of consensus appear to emerge around this term in the residents' statements. The first pertains to the observation that concrete housing appears to have resisted better than other types of structures. The second consensus appears to reveal anxiety regarding the fact that more concrete roofs are being built subsequent to the hurricane. "They've started to add on concrete roofs. It can't be so, I said. You can't put concrete like that just anywhere. That building can't support $i^{\prime \prime}$; "the problem when people add concrete roofs is that you mustn't do that, because we have earthquakes here".

\subsubsection{Identities and Future on the Island of Saint Martin (Class 3)}

This theme accounts for approximately $19 \%$ of utterances. It is entitled "identities and future on the island of Saint Martin". These themes are mainly evoked through the significant presence of words such as "people" (X2 = 228; $p<0.001)$, "to live" (X2 = 167; $p<0.001)$, "island" $(X 2=150 ; p<$ $0.001)$, or "life" $(X 2=135 ; p<0.001)$. These statements, which are far less consensual than the preceding ones, nonetheless appear to be evocative of the lifestyles and specificities of the island of Saint Martin. Initially, the inhabitants described the physical recovery of the island, but also their psychological recovery (or the absence of it): "You have to keep going, because it isn't over, you're alive"; "there are an awful lot of people who still aren't feeling good and don't have the opportunity to take some time out". However, certain inhabitants of West Indian origin believe that there are differences in how people experience a hurricane: "It might have been normal in France to see children cry and people at the end of their rope. This happened in the West Indies and they're strong, they've been whipped so when it comes to a hurricane..." Moreover, many inhabitants, whatever their origin, are apparently very attached to their island, despite Hurricane Irma. Secondly, the inhabitants describe the values and specificities of their island. Saint Martin is nicknamed the friendly island (nickname used by inhabitants to name their island): "Fraternity and exchange inspired its nickname as the friendly island, and there are two sides of the island ... that was our aim, our value regarding the island". Additionally, this small, remote island functions differently from mainland France, or Guadeloupe and Martinique: "The trouble is that we're on a very remote island that doesn't even have the same structures as Guadeloupe". The island also attracts many tourists, and its economy is almost entirely based on tourism. Finally, certain inhabitants wonder about their island's future and would like a shared project and long-term vision to be defined: "Saint Martin is at a crossroads that depends on what will be decided-either our island will become more attractive or it will fall really low"; "the direction we want the island to take and saying there's only one path and that means a degree of discipline, and a degree of recovery." 


\subsubsection{Medical and Psychological Aid and Actors from the Voluntary Sector (Class 4)}

This part represents approximately $19 \%$ of the statement and is entitled "medical and psychological aid and actors from the voluntary sector". These themes are mainly evoked through the significant presence of words such as "psychologist" $(X 2=224 ; p<0.001)$, "population" $(X 2=171$; $p<0.001)$, and "voluntary association" $(\mathrm{X} 2=138 ; p<0.001)$. This category is highly correlated with class 3 (identities and future of the island of Saint Martin), as highlighted in Figure 7. Therefore, the accounts given here are to be interpreted in the light of the latter. Indeed, the word "psychologist" is overrepresented in this category, and so analysis of the utterances around this term reveals a certain number of elements. (1) Some inhabitants apparently do not feel or no longer feel psychologically troubled, and consequently feel no need to consult a psychologist: "There are psychologists on the island at the hospital, I didn't say no but I don't have any problems". (2) Part of the population still suffers from psychological repercussions in the aftermath of Hurricane Irma. This takes the form of significant exhaustion, moroseness, or aggressiveness at times: "People are a little more tense. People are tired. People are morose. I'm even surprised there haven't been more suicides on Saint Martin because it was extremely traumatic". This fatigue is all the more striking in the "helpers", be they professionals or private individuals (adults helping their elders): "We'll see for me. I cancel my own needs. We'll see later. But I was exhausted"; "I think the worst burnouts are in the hospital workers". (3) A great majority of the respondents agree that 18 months after the hurricane, the island needs a significant number of psychologists, especially for the elderly, children, and adolescents: "There's a lack of psychological support, particularly for children and the elderly"; "getting a psychologist here ... it's a rare commodity, oh yes, psychologists are pretty thin on the ground". As for the word "association", this essentially refers to a highly diverse and active voluntary sector on the island of Saint Martin, which overall was extremely helpful in the island's recovery.

\subsubsection{Economic Problems Linked to Post-Disaster Recovery (Class 5)}

This final section is relatively distinct from the others (Figure 7), but is no less important as it accounts for around $16 \%$ of the statements. It is entitled "economic problems linked to post-disaster recovery". These problems are mainly conveyed through the very significant presence of words such as "to pay" ( $\mathrm{X} 2=452 ; p<0.001)$, "insurance" ( $\mathrm{X} 2=171 ; p<0.001)$, "money" ( $\mathrm{X} 2=138 ; p<0.001)$, "expensive" (X2 = 167; $p<0.001)$, "rent" (X2 = 152; $p<0.001)$, and "reconstruct" (X2 = 140; $p<0.001)$. Analysis of these utterances seems to demonstrate that these problems are centered around (1) insurance, (2) the sharp rise in accommodation prices, and (3) the slow pace of recovery.

Initially, most of the inhabitants seem to have a relatively negative image of insurance. This is conveyed in utterances such as: “No point in talking to you about insurance companies, let's just forget about them. Insurance is the only black spot about Irma. Because the companies didn't play fair because they were overwhelmed". Moreover, the accounts reveal a lack of "insurance culture" in a section of the inhabitants, notably those of West Indian origin. Yet the devastation of Hurricane Irma may change attitudes and behaviors toward insurance policies: “We don't have any insurance, we've got insurance on our loans and everything, but it wasn't really our style here to take out house insurance but now we're going to because you need insurance because there are more and more hurricanes". Moreover, the respondents' accounts suggest that another post-disaster consequence is a sharp hike in rents, notably due to the shortage of housing. Finally, the utterances describe a long, expensive recovery, contributing to the exhaustion of the population that was mentioned in Section 4.3.3: "We're tired. I admit I'm annoyed that things aren't moving ahead. We want to be in our home". In addition to these difficulties, people have doubts about the reconstruction, which apparently is not always carried out in compliance with standards: "People are building a little any old how and in a rush. Not necessarily according to the rules and I'm praying there won't be ... well, I'm praying we won't have a hurricane, even of medium intensity, because I think there'll be more damage than with Irma". 


\section{Discussion}

\subsection{Crisis Management of the Immediate Aftermath of the Disaster}

Regarding the immediate consequences of Hurricane Irma, the statements testify to the storm's unprecedented violence and the devastating shock to the island's inhabitants and infrastructure [16]. In addition to this shock, a certain number of stores and homes were looted during and after the hurricane. The lootings, which were tolerated in part (for basic foodstuffs), appear to have caused feelings of insecurity, together with indignation when the stolen goods were products that were not essential for survival. Looting and its consequences are regularly observed phenomena during natural disasters, such as the earthquake in Port-au-Prince in 2010 [17] or Hurricane Katrina in 2005 [18]. The five categories identified by our psycho-sociological approach demonstrate the highly abnormal character of this crisis and highlight the markers of insecurity felt by the local population. This feeling of insecurity includes material, social, identity, and psychological aspects.

The national and local authorities were also affected by this disaster, requiring them to provide responses to deal with the urgency of the crisis. The French state has committed significant human (3000 people) and material (two million bottles of water, 350 tons of food, etc.) resources to help and organize crisis management, at a total cost of 163 million euros [2]. At the same time, there were emergency dispatches to Saint Martin of several teams of experts, sometimes without coordination with all the local stakeholders. For instance, the French Environment Ministry commissioned two teams of flooding experts, in September and early October 2017, to model a new map of the sea flooding hazard in the event of a hurricane. The scales of local, regional, and national discussion need to be better articulated in the particular context of reconstruction. Nevertheless, Hurricane Irma revealed strong structural dysfunctions in the governance of the island. As previously explained (see Section 2), the gradual withdrawal of the management of Saint Martin by the French state following the autonomy obtained in 2007 was one of these factors, among others (governance of Saint Martin's local authorities). In the aftermath of Hurricane Irma, the French state opted for massive reinforcement of its presence on Saint Martin, starting with the creation of a temporary structure to support short-term recovery (the interministerial reconstruction delegation).

To reduce these dysfunctions in the post-disaster phase, the responsibilities of each of the local and national actors in the reconstruction phase following a natural disaster need to be clarified. The actors in charge of public risk prevention policies (the French state, local authorities) have little knowledge of the recovery phase and need to develop training and acculturation actions based on the importance of managing this period.

\subsection{Mid- and Long-Term Recovery Post-Irma}

After the first weeks, social and psychological recovery, together with the rebuilding of infrastructure, are essential priorities [16]. In general, the emergency climate of recovery, which is by nature conflictual, does not allow enough time to devise a more resilient reconstruction project and plays in favor of identical reconstruction [19-21]. The recovery of the island of Saint Martin is no exception to this observation. Faced with the population's distrust of the authorities, who are reflecting on how to rebuild better, the French state and the local authorities of Saint Martin are encountering many difficulties in exchanging serenely with the population [22]. The population of Saint Martin fears that they will be expropriated from their homes close to the coast and be forced to live in an area less exposed to sea flooding. Previous studies highlighted that displacement of the people affected by this prohibition to rebuild is also likely to pose major difficulties [23,24]. In view of the extent of the damage generated by Irma, the French state decided to modify as quickly as possible the urban planning rules on Saint Martin in sectors exposed to natural hazards (the Natural Hazards Prevention Plan). The French state created a permanent local unit in charge of development and risks (Figure 6). This unit is in charge of the elaboration of this new Natural Hazards Prevention Plan. Nevertheless, most of the staff assigned to this new department in charge of urban planning and risk management were temporary and had little experience of the local context. 
Several public meetings to present the new urban planning rules to the population were cancelled by the state (May-June 2019) due to the high levels of tension during the presentations. These tensions reached their climax in December 2019, with the blocking of roads to stop traffic on the island; the major demand of the social movement was the dropping of the newly approved Natural Hazards Prevention Plan [25,26]. Once the initial emergency of the crisis had passed, a feeling of mistrust grew among the population of Saint Martin, calling into question the legitimacy of the instances (local and national authorities), the recovery plan being implemented without taking the residents' experience into account.

Two directions emerge from the interviews conducted with the inhabitants regarding their recovery and their economic and social support-on the one hand the harmful consequences, and on the other the positive changes.

Regarding the harmful consequences, the majority of respondents, as of April 2019, say that they are psychologically exhausted, notably owing to the slow pace of recovery. Some of the interviewees were concerned about the psychological welfare (aggressiveness, nightmares, etc.) of the inhabitants of Saint Martin. These various utterances suggest that part of the population is still suffering from depression or even posttraumatic stress $[27,28]$. Finally, even if psychological treatment is offered after exceptional events [29], it emerged that 18 months after the Irma disaster, extremely few patients had been accepted for psychological care owing to the very small number of psychologists in the French part of the island. According to certain accounts given in April 2019, the French part of Saint Martin has one full-time psychologist at the hospital in Marigot and another psychologist splitting her time between Marigot and a voluntary association.

It would also appear that the hurricane led to some positive changes for certain inhabitants, such as their volunteering with associations. In addition, the French state decided to reinforce its presence on Saint Martin following Hurricane Irma, notably by creating a permanent local unit in charge of development and risks (Figure 6) and including people from Saint Martin in its staff. This decision is perceived positively in the inhabitants' responses as generating meaning and recognition in the workplace, suggesting that post-traumatic growth is emerging [30,31].

Generally speaking, the inhabitants have doubts regarding the reconstruction of buildings and how the vulnerable are taken care of. In this respect, they would like a shared project to be defined for the future of Saint Martin, as despite Hurricane Irma the population is very attached to their "friendly island" and wishes to remain living there, despite the slow pace of socio-economic recovery, exhaustion, and the threat of various climate change hazards.

Nevertheless, the revision of the Natural Hazards Prevention Plan has crystallized tensions and fears that the inhabitants express regarding the future of their properties, as well as for their own futures. Overwhelmed by the scale of the crisis and the management of the reorganization of the territory, neither the French state nor the local authorities of Saint Martin have found the time necessary for consultation with the population regarding the recovery project and the future of their territory. The tensions around the Natural Hazards Prevention Plan strongly illustrate the consequences of this neglect of the population by local institutions in the medium- and long-term, as well as the psycho-sociological distress of the population, which we perceived through this work.

In summary, some Saint Martin's inhabitants were able to benefit from psychological support during the emergency phase, since organizations such as EPRUS (Établissement de Préparation et de Réponse aux Urgences Sanitaires) and the Red Cross were present during the three months following the disaster. As a result, the problem lies in medium- and long-term psychological care; this study underlines the fact that this support is almost non-existent. However, this lack of care probably contributes (1) to the feeling of abandonment of the population, (2) to the development or continuation of psychological disorders (depression, post-traumatic stress disorder, etc.), and (3) to deleterious psychosocial outcomes (feeling of discrimination, intrafamily violence, etc.). Consequently, after a disaster of this magnitude, we can only recommend external and sustainable reinforcement of bilingual psychologists trained in psychotrauma. This reinforcement is all the more crucial because of the island's context. However, it is difficult to establish this type of support without taking into account the context in which it takes place. Indeed, the housing shortage resulting from 
the hurricane and the increase in rental prices maybe represent obstacles to the implementation of these recommendations.

\subsection{The Difficult Post-Irma Recovery: The Fruit of a Historical Legacy}

The history of building construction on Saint Martin from 1954 to 2017 enabled two main results to be identified. On the one hand, there has been no strategy for construction or reconstruction to improve protection of the populations from hurricanes and sea flooding (Figures 4 and 5) [32]. Groups of buildings destroyed or damaged by disasters such as Hurricanes Luis (1995), Lenny (1999), Omar (2008), and Gonzalo (2014) (Figure 2) are usually rebuilt in the same location (Figure 5) [32]. The example of the neighborhood of Oyster Pond shows groups of buildings impacted at least twice by hurricanes. Some buildings were even completely destroyed (Figure 5B), for example in 2004, and reconstructed in exactly the same area after the disaster (Figure 5C). These building were moderately impacted by Hurricane Gonzalo in 2014 and finally damaged by Hurricane Irma in 2017.

On the other hand, the transition from an agrarian economy to one based on tourism from the 1960s onwards [33,34] has gradually heightened the island's vulnerability (Figure 4) [35]. The desire to attract a higher number of tourists has led to numerous buildings being erected in risk areas such as the zones vulnerable to sea flooding (Figure 4) [36]. Several tax exemption laws have stimulated this development of the tourist industry (legislation from the Pons law of 1986 onwards [37]). The numbers of people and buildings considerably increased from the second half of the 20th century to the beginning of the 21st century (Figures 3 and 4, Table 2).

Numerous dwellings were built in the island's highest risk zones (Figure 4C) subsequent to the development of the island's tourist economy, which are generally occupied by the most disadvantaged populations [38-40]. A case in point is the neighborhood of Sandy Ground, which developed in the late 1980s (Figure 4C) to accommodate immigrant workers who came to the island for employment as part of a vast construction program of hotels and tourist accommodation [39]. The construction workers' housing, which is highly exposed to sea flooding hazards, was generally built in non-compliance with anti-hurricane and earthquake norms, and therefore lacks resistance and is extensively impacted by natural disasters. Moreover, these low-income populations usually have no insurance and cannot afford to engage in and complete the reconstruction of their residence [32], as highlighted by class 5 "economic problems linked to post-disaster recovery" from the analysis of the psycho-sociological interviews (see Section 4.3.5). The repairs are, therefore, slow or even extremely slow [2]. While the inhabitants may have psychological issues in the aftermath of a disaster, these problems tend to continue long-term and worsen through a vicious circle of non-improvement of the general situation. Notwithstanding this, the respondents' accounts taken as a whole convey a very significant affective link between the population of Saint Martin and their island. This link, originating in the dynamic interaction between a person and their environment, is connected to the theory of place attachment [41]. According to this theory, place attachment is strongly linked to life satisfaction [42]. Therefore, this attachment is probably one of the psycho-sociological factors explaining the inhabitants' desire to continue living on Saint Martin for the time being, despite exhaustion and the hurricane threat.

The social unrest that occurred in December 2019 in order to challenge the new urbanization regulations in sea flooding risk zones highlighted the fragilities and tensions pre-existing before Irma. On the one hand, a partial explanation for the origin of this movement is the choice of a very heavyhanded authoritarian procedure by the French state imposed on the island's inhabitants in deciding upon the directions for the island's recovery. The very short deadline imposed by the French government for the development of the Natural Hazards Prevention Plan, the necessary consultation with local elected officials and socio-economic actors, and the mandatory presentation of the new rules to the populations resulted in a document deemed very unsatisfactory by the local authorities of Saint Martin and the population. On the other hand, in the year following Hurricane Irma, the local authorities of Saint Martin continued to focus both on post-Irma reconstruction and the projects originally planned in the 2018 budget (taken form the testimony of an executive from the local authorities of Saint Martin). The lack of organization of the plan's technical departments and the low 
number of managers and engineers were strategic errors according to the testimony of technicians from the state and local authorities of Saint Martin. All of these factors contribute to fueling prejudice and mistrust between the local authorities of Saint Martin, the representatives of the French state in Guadeloupe and Metropolitan France, and the socio-economic actors. This respective lack of trust plays a major role in slowing down reconstruction projects.

Once crisis management is over, the post-disaster phase becomes an "experiment" for the affected area because there is no national or international framework to organize the governance of the recovery. As has already been done for a long time in terms of crisis management, it seems important in the future that public authorities think about planning and better supervise the management of recovery.

Such distrust of decision makers by the population is common during the post-disaster recovery phase. Both New Orleans after Hurricane Katrina in 2005 and the city of Chicoutimi in Canada following the Saguenay Flood in 1996 tried to implement projects to rebuild differently after these disasters. In both cases, the redevelopment projects did not take into account the wishes of the citizens and were abandoned $[43,44]$. Recovery planning must give rise to leadership that is supported by all the stakeholders, and which makes decisions and takes on an educational role with the population while remaining sensitive to the latter's demands [45]. Today, the population of Saint Martin has no identified leader to listen to them and fulfill their expectations for the recovery of the island.

This social movement highlighted the specific identity of the population of Saint Martin. This attachment to the island, as evidenced in numerous accounts collected from the inhabitants, can be considered as a factor of the collective resilience of the population of Saint Martin and which enables its inhabitants to find the requisite resources for continuing to live there (the fabric of the voluntary sector, family solidarity, and community solidarity), despite the succession of natural or economic disasters. The fear of partial island abandonment in the face of natural hazards and sea level rise weighs on the population. This phenomenon has already been observed in other island territories, such as Chesapeake Bay, USA [46].

\section{Conclusions}

This interdisciplinary work proposes an analysis of the recovery of the island of Saint Martin following Hurricane Irma according to three points of view: the historical context and the "long" term; the organization of local and national authorities; the perception of the situation by the population. Is Saint Martin less vulnerable today? This is not a foregone conclusion, as can be seen in the tension over the new risk management rules. Such a disaster should have led to profound changes, but the scenario of Hurricane Luis that occurred in 1995 (Figure 2) seems to be repeating itself $[47,48]$.

(1) For over 70 years, the island of Saint Martin has been evolving (Figure 4, Table 2) [11,33], particularly from the late 1980s, which has been accelerated by the tax exemption laws decided by the French state. High population growth (Figure 3) has gone hand in hand with a large number of construction and development projects (Figure 4). Due to the specificities of urban planning linked to tourism, the coast has been extensively urbanized and a situation of fragility has been created in these areas, leading to a decline in the more stable, autonomous economic stage of the agricultural period. Current climate changes suggest that the way has been paved for future disasters. Despite the numerous hurricanes that have impacted Saint Martin since 1960, Saint Martin has mostly adapted to the other disturbances it has faced. The lack of adaptation of the urban planning on the French part of the island of Saint Martin to the natural hazards on the scale of the last 70 years cannot be explained by a lack of rationality or by a deliberate will not to be safe. On Saint Martin, during the period 1954-2017, the most important constraints were not generated by natural disasters, but by pressure related to construction and tourism [32], along with their respective consequences. With regard to the very small size of the French part of the island of Saint Martin $(8 \%$ of Martinique's size), this choice to concentrate the island's economy almost exclusively on tourism has had rapid and strong consequences on its urbanization. 
(2) The reorganization of the French state services on Saint Martin, which was carried out at the same time as the post-Irma recovery, and the political management choices of Saint Martin's local authorities contributed to a lack of visibility of the specific roles of all parties involved in the recovery. Faced with the scale of the crisis and the management of the reorganization of the territory, neither the French state services located in Saint Martin, nor the local authorities, have had any human resources dedicated to consultation with the local population about the recovery project and the future of their territory. All of these factors contribute to fueling prejudice and mistrust between the local authorities of Saint Martin, the representatives of the French state in Guadeloupe and Metropolitan France, and the socioeconomic actors.

(3) The episode of post-disaster management by the French state, which saw the French government directly disavowing confidence in its local services on Saint Martin [49], illustrates the fragilities and tensions pre-existing Irma. On the one hand, there are the conflictual relations between the local authorities of Saint Martin and Saint Martin's State Department, which result in particular from the maladministration of Saint Martin by French state services for years. On the other hand, there are social tensions resulting from the high level of inequality in such a small area [11]. These tensions are particularly evident in the coastal areas, which experience the main natural hazards, contain the main tourist investments encouraged by the local authorities, and contain the most fragile populations (e.g., residents of Sandy Ground), who have no alternative solutions. The long-term uncertainty relating to the new urban planning and construction rules, the feeling that the measures were unequal, and the fact that not all of the alternative projects envisaged could be accomplished did not help in gaining acceptance. Previous work [50], through the extended volcanic case study of Montserrat Island, underscored the need to support the psychological and social recovery of affected social groups, as well as economic and other constraints on policy intervention, in order to adapt to altered post-disaster conditions.

(4) A part of Saint Martin's inhabitants benefitted from psychological support during the emergency phase. Nevertheless, our work highlights the complete absence of medium- and long-term psychological care for the disaster inhabitants. This lack of care probably contributes to the feeling of abandonment of the population, to the development or maintenance of psychological disorders, and to deleterious psychosocial outcomes. It seems essential that the public authorities consider how to better take into account the need for long-term psycho-sociological support in the face of the consequences of natural disasters.

In conclusion, the manner in which Saint Martin's recovery has been managed once again underscores the relevance of planning this phase in ways akin to those already adopted for anticipating and preparing crisis management $[15,51,52]$. The cross-analysis of the three methods used in this study allowed us to better understand the causal links between the governance of the reconstruction, the psycho-sociological recovery of the disaster victims, and the history of the urbanization of an island exposed to natural hazards. The interdisciplinary approach initiated in this work on the subject of post-disaster recovery motivates us to continue this effort of rapprochement and exchange between disciplines in the future, in particular on subjects mixing environmental and societal issues.

Author Contributions: Conceptualization, G.J., A.A., K.P., and O.N.; methodology, G.J., A.A., K.P, O.N., A.H.B., M.-A.C., D.C., G.F.-B., J.G., P.G., and C.T.D.M.; software, A.A and K.P.; formal analysis, G.J., A.A., K.P., and O.N.; investigation, G.J., A.A., K.P, O.N., M.-A.C., D.C., J.G., P.G., and C.T.D.M.; data curation, G.J. and A.A.; writing - original draft preparation, G.J., A.A., K.P, O.N., D.C., J.G., and C.T.D.M.; writing - review and editing, G.J., A.A., K.P, O.N., and C.T.D.M.; supervision, G.J.; project administration, G.J.; funding acquisition, G.J. All authors have read and agreed to the published version of the manuscript.

Funding: This research has been supported by the Relev project funded by the Agence Nationale de la Recherche (ANR), grant number ANR-18-OURA-0004. 
Acknowledgments: All of the people who agreed to give time to the authors to testify about their field experience are gratefully acknowledged. The authors would like to thank the European Copernicus program "Risk and Recovery Mapping", as well as the CNES (Centre National d'Etudes Spatiales) for the provision of geographical and satellite data. We thank the three anonymous reviewers for their useful comments, thorough and helpful reviews.

Conflicts of Interest: The authors declare no conflict of interest.

\section{Appendix A}

Translation of vocabulary used in Figure 7 for the factorial analysis of language. The interviews were conducted in French. We chose to keep French in this figure because our method of discourse analysis is based on this language. We provide here a translation of each word used in this figure, sorted by class. The French version of each word is followed by its English translation.

In green, class 1.Machine: machine; pilleur: looter; trois jours: three days; supermarché: supermarket; ambiance: atmosphere; mercredi: Wednesday; ciel: sky; semaine: week; télé: TV; chaud: hot; gamin: kid; laver: wash; militaire: soldier; armée: army; camion: truck; boire: to drink; deux jours: two days; flic: cop; récupérer: to retrieve; minute: minute; piller: to loot; jeter: to throw away; poubelle: trash can; lundi: Monday; café: cafe; kilomètre: kilometer; gars: lad; vert: green; voir: to see; manger: to eat; pillage: looting; con: idiot; queue: line; frigo: fridge; manguier: mango tree; jour: day; bouteille: bottle; heure: hour; calmer: to calm; bouffe: food; citerne: water tank; arriver: to arrive; machin: thingummy; magasin: shop; matin: morning; route: road; puer: to stink; mec: guy; truc: thing; électricité: electricity; eau: water; soir: evening; luire: to gleam; oeil: eye; nuit: night; passer: to pass; repartir: to leave; durer: to last; nettoyer: to clean; feu: fire; sac: bag.

In grey, class 2. Mère: mother; perdre: to lose; rester: to stay; côté: side; cyclone: hurricane; mer: sea; pleuvoir: to rain; voisin: neighbor; pluie: rain; couler: to flow; habiter: to live; pression: pressure; tôle: sheet-metal; lit: bed; descender: to go down; bas: low; tenir: to hold; fils: electric cables; bouger: to move; dormer: to sleep; couloir: corridor; chance: luck; maison: house; porte: door; bois: wood; fenêtre: window; étage: storey; protéger: to protect; exploser: to explode; toiture: roof; vent: wind; mur: wall; céder: to yield; chambre: bedroom; coin: corner; pièce: room; baie vitrée: picture-window; projectile: projectile; asseoir: to sit; casser: to break; toit: roof; béton: concrete; volet: shutter; mètre: meter; vitre: windowpane; construction: building; collège: high school; éclater: to burst; terrasse: terrace; salon: living-room; trembler: to shake; tornade: tornado; construire: to build; armoire: cupboard; repeindre: to repaint.

In red, class 3. Rencontrer: to meet; forme: health; naturel: natural; pays: country; discuter: to discuss; bouchon: tailback; catastrophe: disaster; continuer: to continue; penser: to think; île: island; tension: tension; connaître: to know; tout le monde: everyone; âge: age; relation: relationship; situation: situation; beaucoup de gens: many people; famille: family; vraiment: really; aider: help; aimer: to like; ça: that; vrai: true; développer: to develop; parler: to talk; gens: people; vivre: to live; saint martin: Saint Martin; façon: way; vie: life; profiter: to take advantage; chose: thing; dur: hard; depuis irma: since Irma; culture: culture; antilles: West Indies; fois: times; choix: choice; quand même: nonetheless; envie: wish; connaissance: knowledge; année: year; ne peut pas: unable.

In blue, class 4. Consulter: to consult; établissement: establishment; France: France; victimes: victims; Disparu: missing; cmp: medical-psychological center; agir: to act; prise en charge: acceptance for treatment; réunir: to meet; conseil de quartier: neighborhood council; docteur: doctor; psychologue: psychologist; actif: active; idée: idea; patient: patient; agent: employee; EPRUS: directorate for emergency preparation and response; directeur: director; infirmier: nurse; assistante sociale: social worker; politique: political; équipe: team; capacité: capacity; cellule: cell; préfète: Prefect; vision: vision; territorial: territorial; conseil: council; élu: elected member; préfecture: Prefecture; quartier d'Orléans: the Orléans district; terme: term; impliquer: to imply; opérationnel: operational; population: population; hôpital: hospital; dispositif: measures; mission: mission; gérer: to manage; place: area; médecin: doctor; ressentir: to feel; centre: center; liste: list; crise: crisis; macron: Macron; quartier: district; c'est: it's; président: president; service: department; réseau: network; chercher: to look for; juste après irma: just after Irma; association: association; aide: help; appeler: to 
call; local: local; public: public; chef: leader; suivre: to follow; réunion: meeting; croix rouge: Red Cross; recevoir: to receive; état: state; travailler: to work; occuper: occupy; moyen: resource; collectivité: authority; niveau: level.

In purple, class 5. Reconstruction: reconstruction; là-dessus: above; mois: month; permettre: to allow; entreprise: company; français: French; dossier: file; compte: account; deux ans: two years; acheter: to buy; six mois: six months; business: business; plan: plan; prêt: loan; utiliser: to use; emploi: job; carte: map; état: state; minimum: minimum; com: local authority; janvier: January; reconstruire: rebuild; insertion: integration; réparer: to mend; société: society; décembre: December; préférer: to prefer; débloquer: to release; contrôle: to check; norme: norm; administratif: administrative; propriétaire: owner; règle: rule; contrat: contract; argent: money; billet: banknote; intervenir: to intervene; cinq ans: five years; banque: bank; catastrophe naturelle: natural disaster; payer: to pay; réparation: repair; prix: price; refuser: to refuse; chantier: building site; assurance: insurance; cher: expensive; coûter: to cost; copropriété: joint ownership; expert: loss adjuster; commerce: shop; gagner: to earn; coincer: blocked; un an et demi: a year and a half; relogement: rehousing; loyer: rent; syndic: property manager; studio: studio apartment; courrier: mail; perso: personal; avenir: future; racheter: to buy again; entrepreneur: entrepreneur.

\section{References}

1. Cangialosi, J.P.; Latto, A.S.; Berg, R. National Hurricane Center Tropical Cyclone Report - Hurricane Irma (AL112017), 2018. Available online: https://www.nhc.noaa.gov/data/tcr/AL112017_Irma.pdf (accessed on 3 July 2020).

2. Gustin, P. Les îles de Saint-Martin et de Saint-Barthélemy, un an après IRMA - Bilan d'une année d'action de l'Etat dans la reconstruction des îles du Nord, 2018. Available online: http://www.guadeloupe.gouv.fr/content/download/14645/96869/file/DP\%20IRMA\%20-

\%20BILAN\%201\%20AN.pdf (accessed on 3 July 2020).

3. Le Point, 2017. Irma : l'île de Saint-Martin "à $95 \%$ détruite". Available online: https://www.lepoint.fr/societe/irma-1-ile-de-saint-martin-a-95-detruite-07-09-2017-2155076_23.php (accessed on 3 July 2020).

4. Gustin, P. Repenser les Iles du Nord pour une reconstruction durable, 2017. Available online: https://www.gouvernement.fr/sites/default/files/contenu/piece-

jointe/2017/11/rapport_de_philippe_gustin_delegue_interministeriel_a_la_reconstruction_21_novembre_ 2017.pdf (accessed on 3 July 2020).

5. Servans, G.; Naulin, A.; Le Corre, L, 2016. Saint-Martin : Terre d'accueil et de contrastes. Insee Dossier Guadeloupe, 10, p. 24. Available online: https://www.insee.fr/fr/statistiques/2527810 (accessed on 3 July 2020).

6. Nicolas, T. Le fragile équilibre d'une île-carrefour : Saint-Martin. In Les dynamiques contemporaines des îlesrelais : de l'île escale aux réseaux insulaires; Bernardie, N., Taglioni, F. Eds.; Karthala: Paris, France, 2005; pp. 163-180.

7. JORF, 2007. Loi organique $\mathrm{n}^{\circ}$ 2007-224 du 21 février 2007 portant dispositions statutaires et institutionnelles relatives à l'outre-mer. Journal officiel de la République française, p. 3220. Available online: https://www.legifrance.gouv.fr/affichTexte.do?cidTexte=JORFTEXT000000641099\&categorieLien=id (accessed on 3 July 2020).

8. Redon, M. Migrations et frontière : le cas de Saint-Martin. Études caribéennes 2007, 8, https://doi.org/10.4000/etudescaribeennes.962.

9. Benoît, C. Saint Martin : un nouveau droit des étrangers. Plein droit 2007, 74, 17-20 https://www.gisti.org/spip.php?article4386.

10. Magnan, A. L'espace littoral a-t-il toujours de la valeur ? Réflexion à partir du cas de l'île de Saint-Martin (Petites Antilles). Norois 2008, 206, 37-52.

11. Redon, M. Saint-Martin/Sint-Maarten, une petite île divisée pour de grands enjeux. Les Cahiers d'Outre-Mer 2006, 234, 233-266.

12. Ratinaud, P.; Déjean, S. IRaMuTeQ : implémentation de la méthode ALCESTE d'analyse de texte dans un logiciel libre. Proceedings of the conference « Modélisation Appliquée aux Sciences Humaines et Sociales ", Toulouse - Le Mirail, France, 2009.

13. Reinert, M. La Méthode informatisée d'analyse de discours «Alceste ». Applications aux « Rêveries du promeneur solitaire ». Proceedings of the $5^{\text {th }}$ Journées Internationales d'Analyse Statistique des Données Textuelles, Lausanne, Switzerland, 10 March 2000; 31. 
14. Roy, N. ; Garon, R. Étude comparative des logiciels d'aide à l'analyse de données qualitatives : de l'approche automatique à l'approche manuelle. Recherches qualitatives 2013, 32(1), 154-180.

15. Crozier, D.; Jouannic, G.; Tran Duc Minh, C.; Kolli, Z.; Matagne E.; Arbizzi, S. Post-disaster Recovery: a Window of Opportunity to Reduce the Territorial Vulnerability? Espace populations sociétés 2016, 3, 20, https://doi.org/10.4000/eps.7033

16. Desse, M.; Gherardi, M.; Charrier, S. Adaptation aux cyclones et au risque de submersion marine dans les communes littorales de Guadeloupe. EchoGéo 2020, 51, 16, DOI : https://doi.org/10.4000/echogeo.19207.

17. Benitez, F. Faire face ou vivre avec les catastrophes ? Capacités d'adaptation et capabilités dans les trajectoires de résilience individuelles et territoriales au sein de l'espace Caraïbe. PhD Thesis, University of Montpellier-Paul Valéry, France, 21 September 2018.

18. Neuilly, M.T. Gestion et prévention de crise en situation post-catastrophe. De Boeck: Paris, France, 2008 ; p. 295.

19. Comerio, M.C. Disaster hits home: new policy for urban housing recovery. $1^{\text {st }}$ ed.; University of California Press: Berkeley, CA, USA, 1998; p. 326.

20. Arendt, L.A.; Alesch, D.J. Long-Term Community Recovery from Natural Disasters. $1^{\text {st }}$ ed.; CRC Press: Boca Raton, Florida, USA, 2014; p. 312. https://doi.org/10.1201/b17677.

21. Olshansky, R.; Chang, S. Planning for Disaster Recovery: Emerging Research Needs and Challenges. Prog. Plan., 2009, 72(4), 200-209.

22. Le Monde, 2019. Blocages, affrontements... vives tensions à Saint-Martin à propos d'un plan prévoyant de nouvelles zones non constructibles. Available online: https://www.lemonde.fr/societe/article/2019/12/17/blocages-affrontements-vives-tensions-a-saint-martina-propos-d-un-plan-prevoyant-de-nouvelles-zones-non-constructibles_6023219_3224.html (accessed on 3 July 2020).

23. Hino, M.; Field C.B.; Mach, K.J. Managed retreat as a response to natural hazard risk. Nat. Clim. Change, 2017, 7, 364-370.

24. Jamero, M.L.; Onuki, M.; Esteban, M.; Billones-Sensano, X.K.; Tan, N.; Nellas, A.; Takagi, H.; Thao, N.D.; Valenzuela, V.P. Small-island communities in the Philippines prefer local measures to relocation in response to sea-level rise. Nat. Clim. Change, 2017, 7, 581-586

25. Soualiga Post, 2019. Sandy Ground s'oppose au PPRN. Available online: http://www.soualigapost.com/fr/actualite/30376/environnement/sandy-ground-s\%E2\%80\%99oppose-aupprn (accessed on 3 July 2020).

26. Libération, 2019. L'île de Saint-Martin connaît-elle une situation insurrectionnelle ? Available online: https://www.liberation.fr/checknews/2019/12/17/1-ile-de-saint-martin-connait-elle-une-situationinsurrectionnelle_1769563 (accessed on 3 July 2020).

27. Ashbaugh, A.R.; Houle-Johnson, S.; Herbert, C.; El-Hage, W.; Brunet, A. Psychometric Validation of the English and French Versions of the Posttraumatic Stress Disorder Checklist for DSM-5 (PCL-5). Plos One 2016, 11(10), 1-16. doi: 10.1371/journal.pone.0161645.

28. Blevins, C.A.; Weathers, F.W.; Davis, M.T.; Witte, T.K.; Domino, J.L. The Posttraumatic Stress Disorder Checklist for DSM-5 (PCL-5): Development and Initial Psychometric Evaluation, J. Trauma. Stress, 2015, 28, 489-498.

29. Lovell, A. Entretien avec Anne Lovell. Rhizome 2015, 57; 4-5.

30. Cadell, S.; Suarez, E.; Hemsworth, D. Reliability and Validity of a French Version of the Posttraumatic Growth Inventory. Open J. Med. Psychol. 2005, 4, 53-65.

31. Tedeschi, R.G.; Calhoun, L.G. The Posttraumatic Growth Inventory: Measuring The Positive Legacy of Trauma. J. Trauma. Stress, 1996, 9, 455-471. doi : org/10.1002/jts.2490090305

32. Pasquon, K.; Jouannic, G.; Gargani, J.; Tran Duc Minh, C.; Crozier, D. Ouragans et évolution de l'urbanisme à Saint-Martin de 1954 à 2017 : Comment nos sociétés se transforment ? VertigO (under review).

33. Monnier, Y. L'immuable et le changeant : étude de la partie française de Saint-Martin; Centre d'études de géographie tropicale du CNRS : Centre de recherche sur les espaces tropicaux de l'université de Bordeaux III: Talence, France, 1981, p. 125.

34. Lasserre G. La Guadeloupe, les îles et leurs problèmes. PhD Thesis, University of Bordeaux, Talence, 1961, p. 1135.

35. Pasquon, K.; Gargani, G.; Jouannic G. Intéraction nature/société de 1947 à 2017: processus, caractéristiques et vulnérabilité à Saint-Martin. 2019, Proceedings of the Conference « Vulnérabilité et Résilience dans le renouvellement des approches du développement et de l'environnement », Guyancourt, France, 13 November 2019.

36. Pagney Bénito-Espinal F. Les catastrophes naturelles : des entraves au développement dans le bassin caraibe. In La Caraïbe, données environnementales; Joseph, P. Ed.; Karthala et GEODE Caraïbe: Paris, France, 2006; pp. 17-32. 
37. JORF, 1986. Article 22 de la loi $n^{\circ} 86-824$ du 11 juillet 1986 de finances rectificative. Journal officiel de la République française.

Available

online: https://www.legifrance.gouv.fr/affichTexte.do;jsessionid=0D1340B95C5A4813514E4109C224C93E.tplgfr34 s_2?cidTexte=JORFTEXT000000512460\&dateTexte= (accessed on 3 July 2020).

38. Jeffry, D. Déstabilisation sociétale dans la caraïbe française ; L'Harmattan: Paris, France, 2010; p 254.

39. Chardon, J-P.; Hartog, T. Saint-Martin ou l'implacable logique touristique, Cahier d'outre-mer 1995, 189, 2133.

40. Marie, $\mathrm{C}-\mathrm{V}$, Travail illégal et immigration irrégulière dans les départements d'Outre-mer. Le cas : SaintMartin, 1991. Rapport de mission pour le Ministère du travail. Available online: https://www.gisti.org/doc/publications/1996/bananier/saint-martin/rapport-marie.pdf (accessed on 3 July 2020).

41. Schumaker, S.; Taylor, R. (1983). Toward a clarification of people-place relationships: A model of attachment to place. In Environmental psychology. Directions and perspectives; Feimer N., Geller, S., Eds.; Praeger: New-York, NY, USA, 1983, pp. 219-251.

42. Rioux, L.; Mokounkolo, R. Validation en langue française d'une échelle d'ancrage territorial. Can. J. Behav. Sci., 2010, 42(3), 150-157.

43. Campanella, T. Urban Resilience and the Recovery of New Orleans. J. Am. Plan. Assoc., 2006, 72, 141-146.

44. Jouannic, G.; Crozier, D.; Tran Duc Minh, C.; Kolli, Z.; Arki, F.; Matagne, E.; Arbizzi, S.; Bomperin, L. Postdisaster recovery: how to encourage the emergency of economic and social dynamics to improve resilience? Proceedings of the 3rd European Conference on Flood Risk Management, Lyon, France, 17-21 October 2016; E3S Web Conf. Eds.,Lyon, France, 7, 201617004.

45. Maret, I.; Cadoul, T. Résilience et reconstruction durable : que nous apprend La Nouvelle-Orléans ? Annales de Géographie 2008, 663, 104-124.

46. Arenstam Gibbons, S.J.; Nicholls, R.J. Island abandonment and sea-level rise: An historical analog from the Chesapeake Bay, USA. Global Environmental Change 2006, 14, 40-47.

47. Duvat, V. Le système du risque à Saint-Martin (Petites Antilles françaises). Développement durable et territoires 2008, 11, p. 23. DOI : https://doi.org/10.4000/developpementdurable.7303

48. Veyret Y. Une catastrophe inévitable : Saint-Martin (Antilles), une île à risques majeurs. Diploweb.com : la revue géopolitique 2017. Available online: https://www.diploweb.com/Une-catastrophe-inevitable-SaintMartin-Antilles-une-ile-a-risques-majeurs.html (accessed on 3 July 2020).

49. Le Figaro, 2019. Saint-Martin: Girardin promet que le plan à l'origine des tensions sera «corrigé». Available online: https://www.lefigaro.fr/flash-actu/saint-martin-girardin-promet-que-le-plan-a-l-origine-destensions-sera-corrige-20191217 (accessed on 3 July 2020).

50. Monteil, C.; Sommons, P.; Hicks, A. Post-disaster recovery and sociocultural change: Rethinking social capital development for the new social fabric. International Journal of Disaster Risk Reduction 2020, 42, Article 101356, p. 9. https://doi.org/10.1016/j.ijdrr.2019.101356.

51. Berke P.R.; Kartez J.; Wenger D. Recovery after disaster: achieving sustainable development, mitigation and equity. Disasters 1993, 17(2), 93-109.

52. Moatty, A. Pour une géographie des reconstructions post-catastrophe : Risques, Sociétés et Territoires. PhD Thesis, University of Montpellier - Paul Valéry, France, 14 December 2015.

Publisher's Note: MDPI stays neutral with regard to jurisdictional claims in published maps and institutional affiliations.

(C) 2020 by the authors. Licensee MDPI, Basel, Switzerland. This article is an open access article distributed under the terms and conditions of the Creative Commons Attribution (CC BY) license (http://creativecommons.org/licenses/by/4.0/). 